\title{
Opportunities and Barriers to Bioenergy Conversion Techniques and Their Potential Implementation on Swine Manure
}

\author{
Mahmoud A. Sharara ${ }^{1}$ and Sammy S. Sadaka ${ }^{2, *}$ \\ 1 Biological Systems Engineering Department, University of Wisconsin-Madison, Madison, WI 53706, USA; \\ msharara@wisc.edu \\ 2 Biological and Agricultural Engineering Department, Division of Agriculture University of Arkansas, \\ Little Rock, AR 72204, USA \\ * Correspondence: ssadaka@uaex.edu; Tel.: +1-501-671-2298
}

Received: 28 March 2018; Accepted: 13 April 2018; Published: 17 April 2018

\begin{abstract}
The objectives of this article are to offer a comprehensive evaluation of the opportunities and barriers for swine manure conversion technologies and to shed light on the gaps that might require further investigation to improve the applicability of these technologies. The challenges of manure management have been propagated alongside the global growth of swine production. Various technologies that target the production of energy, fuels, and bioproducts from swine manure have been reported. These technologies include pretreatments, i.e., drying, and solid separation; biological techniques, i.e., composting, anaerobic digestion, and biodrying; and thermochemical techniques, i.e., combustion, gasification, pyrolysis, liquefaction, and carbonization. The review highlights the yields and qualities of products, i.e., energy, gaseous fuel, liquid fuel, and solid fuel, of each technology. It exhibits that the choice of a conversion technology predominantly depends on the feedstock properties, the specifics of the conversion technique, the market values of the end products as well as the local regulations. The challenges associated with the presented techniques are discussed to ameliorate research and development in these areas. The notable finding of this paper is that there is a need for full-scale research in the area of thermochemical conversion of solid-separated swine manure.
\end{abstract}

Keywords: swine manure; biological conversion; anaerobic digestion; composting; biodrying; thermochemical conversion; combustion; gasification; pyrolysis; liquefaction; carbonization

\section{Introduction}

The United States Department of Agriculture (USDA) inventory reported that the number of pigs had reached 70.7 million heads in 2017 [1]. The growth in the pig inventory can be correlated to an increase in the swine manure production. The annual cumulative swine manure generated could reach 120 million metric tons (MMT) year ${ }^{-1}$ based on the assumption that the daily manure production per pig is about $4.67 \mathrm{~kg} \cdot \mathrm{day}^{-1}$ [2]. This vast amount of manure production has created a substantial challenge to the swine sector mainly due to the concentration of swine production [3]. It has been reported that about $85 \%$ of the national swine inventory produced in the USA is centered in the Midwestern states including Iowa, Minnesota, Illinois, Indiana, Nebraska and Kansas which are among the top ten producing states [4]. Research has also revealed that, out of the 69,000 swine operations, about $87 \%$ house 2000 heads or more [1].

The concentrated swine manure production, with the limitation of available land to apply manure as fertilizer has created a need to develop various technologies to convert this feedstock into bioenergy and/or value-added products. Bioenergy signifies the most essential renewable energy source [5]. 
It can add to fulfil, in a sustainable manner, the future energy requirements [6,7]. The conversion technologies could be classified as biological and thermochemical technologies. Biological techniques include composting, anaerobic digestion, and biodrying while thermochemical techniques include combustion, gasification, pyrolysis, liquefaction, and carbonization. Despite the success of developing various swine manure conversion technologies, some challenges still limit their large-scale applicability. The difficulties of swine manure conversion techniques include high moisture content, low calorific value, the scatter distribution that makes collection difficult and results in economic problems and deficiencies in transportation, handling, storage, and conversion. The present review focuses on the illustration of these technologies as well as the challenges facing them.

\section{Swine Manure Composition and Characteristics}

Swine manure composition data is highly varied, as shown by a survey of the available literature. This occurrence is occasioned by the fact that manure composition is incumbent upon various factors including, animal feed composition, animal age, and genetics. Additionally, the manure handling system alters the properties and composition of raw manure. Moreover, manure composition data are often reported using different matrices, i.e., as excreted, or as-removed basis. The latter option, as-removed basis, factors in the influence of the handling method on the composition and the properties of the manure. Table 1 below presents the various characteristics of swine manure for the animals at different stages. It is clear that, regardless of stage, the swine excrements are predominantly water, with the total solids making only $10 \% w / w$ of the manure.

Table 1. The weight of pigs at different stages and the corresponding characteristics of manure as-excreted [2].

\begin{tabular}{ccccc}
\hline Component & Units & Gestating Sow & Lactating Sow & Boar \\
\hline Animal weight & $\mathrm{kg}$ & 200 & 192 & 200 \\
Total Manure & $\mathrm{kg} \cdot \mathrm{day}^{-1} \mathrm{animal}^{-1}$ & 5.00 & 12.00 & 3.80 \\
Moisture Cont. & $\%$, w.b. & 90.00 & 90.00 & 90.00 \\
TS & $\mathrm{kg} \cdot \mathrm{day}^{-1} \mathrm{animal}^{-1}$ & 0.50 & 1.20 & 0.38 \\
VS & $\mathrm{kg} \cdot \mathrm{day}^{-1} \mathrm{animal}^{-1}$ & 0.45 & 1.00 & 0.34 \\
BOD & $\mathrm{kg} \cdot \mathrm{day}^{-1} \mathrm{animal}^{-1}$ & 0.17 & 0.38 & 0.13 \\
N & $\mathrm{kg} \cdot \mathrm{day}^{-1} \mathrm{animal}^{-1}$ & 0.03 & 0.09 & 0.03 \\
P & $\mathrm{kg} \cdot \mathrm{day}^{-1} \mathrm{animal}^{-1}$ & 0.01 & 0.03 & 0.01 \\
K & $\mathrm{kg} \cdot \mathrm{day}^{-1}$ animal $^{-1}$ & 0.02 & 0.05 & 0.02 \\
\hline
\end{tabular}

\section{Swine Manure Pretreatments}

Manure is an essential source of nutrients, predominantly nitrogen $(\mathrm{N})$, phosphorus $(\mathrm{P})$, and potassium $(\mathrm{K})$, to plants when applied in an ecologically sustainable manner [8,9]. Conventionally, land application of swine manure is considered the most recognized practical and economical utilization technique [10]. However, repeated manure application on the same field elevate the $P$ concentration levels, which may harm the environment via surface runoff or leaching of $\mathrm{P}[11,12]$. As mentioned earlier, the moisture content and total solids of fresh swine manure are approximately $90 \%$ w.b. and $10 \%$ w.b., respectively [2]. The high moisture content of manure tends to limit its long-distance transportation. Accordingly, research focused on reducing manure moisture content and concentrate the solid content via drying and solid separation.

\subsection{Manure Drying}

Manure could be dried to reduce its moisture content and to concentrate the solids via evaporation of water, thus reducing its volume. Animal manure used to be dried using old-fashioned techniques, i.e., oven-drying and hot air-drying. Typically, additional heat and/or forced air is desirable to enhance faster evaporation of moisture [13,14]. The advantage of dried manure is the reduction of 
microorganisms or insects growth. Additionally, dried manure has less odor as compared with fresh manure. Also, dry manure could be utilized as a soil fertilizer in the same manner that composted manure is utilized. The substantial disadvantages of drying manure are the high energy requirements and the costs associated with moisture removal. In a 100\% efficiency dryer, the thermal energy required to evaporate $1 \mathrm{~kg}$ of moisture from manure was described to be $2.3 \mathrm{MJ}$ [15]. This energy and the associated cost are incredibly high and cannot be fully recovered from the sale of the dried manure, which makes it economically unacceptable to producers. Drying systems also must be covered to keep manure away from rainfall.

\subsection{Manure Solid Separation}

Liquid and solid segments of swine manure could be separated and employed via various techniques to convert them to value-added products and to minimize their harmful effects [16]. Employing solid-liquid separation as a technique for manure treatment not only potentially enhances its management properties but also produces manure solids that might be exploited for either energy generation or compost [17]. Separation of solids from liquid manure could be achieved via sedimentation (gravity settling), centrifugation, filtration (using belt presses, screw presses, and screens), or chemical amendment $[18,19]$. The separated solid fraction of swine manure is rich in nutrients, particularly $\mathrm{P}$, and can be transported for land application on soils with poor $\mathrm{P}$ concentrations. The liquid portion can be used to irrigate soils without considerably increasing their P levels [20]. Xiu et al. [21] stated that chemical separation of manure solids could be achieved using metal salts and organic flocculants that transport solubilized nutrients out of solution as fine particles. Following, it forms agglomerates of these salts, which can then rapidly precipitate. Normally used chemical amendments are metallic salts, i.e., iron (Fe), calcium $(\mathrm{Ca})$, or aluminum $(\mathrm{Al})$ and synthetic organic polymers, i.e., polyacrylamide (PAM) formulations [22]. Addition of coagulants, i.e., $\mathrm{FeCl}_{3}, \mathrm{Fe}_{2}\left(\mathrm{SO}_{4}\right)_{3}, \mathrm{Al}_{2}\left(\mathrm{SO}_{4}\right)$, and $\mathrm{CaCO}_{3}$, to manure results in coagulation of suspended particles by neutralizing the particles' negative surface charge and enhances $\mathrm{P}$ removal via coagulation of $\mathrm{P}$ by the cations constituting the coagulants [23]. Christensen et al. [24] and Sadaka and VanDevender [16] reported that treatments of animal manure with coagulants and flocculants enhanced solid-liquid separation. It has been reported that the overall energy balance presented a reduction of $0.596 \mathrm{MJ} \cdot \mathrm{kg}^{-1}$ for the pyrolysis of the chemically pre-treated manure, whereas positive values of $0.352 \mathrm{MJ} \cdot \mathrm{kg}^{-1}$ and $0.817 \mathrm{MJ} \cdot \mathrm{kg}^{-1}$ were found for anaerobically digested sample and un-pretreated solid swine manure, respectively [25].

\subsection{Challenges Associated with Swine Manure Pretreatments}

As mentioned earlier, the energy consumption to dry manure is exceptionally high. Accordingly, an enhancement of the manure drying technology can considerably advance the overall impacts of swine manure management via thermochemical conversion. Manure solid separation using chemicals or mechanical methods add more costs to the manure management system which reduce the overall benefits to producers. Therefore, simple and affordable techniques to separate the solid portions from the liquid portion of manure need to be investigated. Swine manure drying using infrared technology or microwave drying systems could potentially be economic ways to reduce manure moisture content.

\section{Biological Treatments of the Swine Manure}

Biological processes target the elimination of pathogens, weed seeds, and parasites. Additionally, they amend the manure composition from a complex, malodorous effluent to an odor-free, plant-accessible one. Furthermore, biological treatments decrease the manure nutrient loading, thus minimizing the risk of over-application or nutrient runoff [26]. In general, most swine farms utilize at least one type of biological treatment. Biological treatments could take place in aerobic and anaerobic conditions as well as low temperature (mesophilic, $25-35^{\circ} \mathrm{C}$ ) or high temperature (thermophilic, above $50^{\circ} \mathrm{C}$ ) [27]. Manure matrix maintained within thermophilic conditions for a few 
days is usually sufficient to kill pathogens. However, manure composition modification is achieved through a sequence of decomposition stages that digest the complex organic species in the manure (proteins, fibers, fat, and organic acids) into uncomplex, short-chain compounds while releasing gaseous emissions of $\mathrm{NH}_{3}, \mathrm{CO}_{2}, \mathrm{CH}_{4}$, and VFAs through aerobic and anaerobic digestion.

Manure management in farms above 2500 heads falls under the purview of Environmental Protection Agency's (EPA) concentrated animal feeding operation (CAFO) guidelines [28]. Soil application in such cases is regulated through a permitting process. Application permits are tied to manure quality only from a nutrient loading perspective, unlike with municipal sludge in which permitting tracks both composition and pathogen loading before permitting soil application. Permitting also ensures that the targeted agricultural land is capable of assimilating the intended manure volumes through soil nutrients analysis. In the following sections, we will explore swine manure biological treatments, i.e., composting, anaerobic digestion, and biodrying.

\subsection{Swine Manure Composting}

For centuries, animal farming has practiced aerobic composting of animal manure. It serves as a treatment that reduces odors and moisture, also, to eliminate pathogens and to improve the manure properties as a soil conditioner. The process is achieved through a series of oxidation and mineralization stages carried out by aerobic microorganisms (mesophilic and thermophilic), which convert the biomass matrix into a stabilized, humus-like substance [29]. The composting process requirements and outcomes are given by the following formula [30]:

$$
\text { fresh organic waste }+\mathrm{O}_{2} \stackrel{\text { microbial metabolism }}{\longrightarrow} \text { stabilized organic residue }+\mathrm{CO}_{2}+\mathrm{H}_{2} \mathrm{O}+\text { Heat }
$$

The rate of carbon and nitrogen mineralization is triggered by the elevated temperatures achieved during activation of thermophilic bacteria. Incomplete aerobic digestion happens naturally in the bedding mixture (crop residue, and animal manure) under hoop structure swine feeding. By scraping it into piles or windrows, the bedding-manure mixture is often enabled to continue compositing between herds [31]. To facilitate aerobic conditions in wet-handling systems, where manure is flushed and collected in lagoons, a solid-separation step is necessary to increase the solid content of the matrix.

The levels of microbial activity and the phytotoxicity of the decomposed matrix remains the most critical determinants of the composting process [32]. From a temperature standpoint, the process can be separated into three consecutive stages: heating, thermophilic, and cooling phases. The heating phase, which starts immediately after mixing the biomass and setting the piles, is typically the shortest. The stage usually lasts $1-3 \mathrm{~h}$, during which the compost pile temperatures increase rapidly from ambient to thermophilic levels, above $50{ }^{\circ} \mathrm{C}$. The temperatures are sustained all across the thermophilic phase, the period of which depends on the nature of the mixture, and the aeration levels. Mineralization and oxidation rates are at their highest during this stage, resulting in volatilization of $\mathrm{NH}_{3}, \mathrm{CO}_{2}$, and evaporation of moisture. This phase is critical for killing pathogens, parasites, and weed seeds. Therefore, for the compost to be deemed safe, it should remain at this stage, at $55^{\circ} \mathrm{C}$, for at least three days [33]. The last stage is cooling and stabilization, which is typically the longest and it ends with the material thoroughly degraded and pathogen-free.

The composting process parameters (aeration, $\mathrm{C} / \mathrm{N}$ ratio, moisture, $\mathrm{pH}$, and temperature) should be appropriately managed to produce a stabilized, pathogen-free compost within a suitable timeframe. Most importantly, there are no sufficient $\mathrm{C}$ and $\mathrm{N}$ levels in swine manure $(\mathrm{C} / \mathrm{N}$ ratio) to initiate and sustain composting by itself as it is evident in Table 2. Accordingly, introducing a carbon-rich source, i.e., wood chips, sawdust, or crop residue, to adjust the $\mathrm{C} / \mathrm{N}$ ratio is the first step to initiate manure composting [34]. The recommended $\mathrm{C} / \mathrm{N}$ range of $25-35$ and the moisture content range of $50 \%$ and $60 \%$ w.b. are optimum conditions for the starting of the composting process. Excessively high temperatures $\left(>60^{\circ} \mathrm{C}\right)$, or rapid drying of the pile resulted in rapid decomposition in the initial phase but a limited activity of bacterial population, and eventual termination of the composting process [31]. 
Effects of aeration rates, both perpetual and intermittent, on maintaining a thermophilic environment for a blend of swine manure separated solids, and peat moss in an in-vessel composting setup was investigated [35]. Within 15 days of composting, the $\mathrm{C} / \mathrm{N}$ ratio decreased from 15-18 to 10-14. Likewise, the $\mathrm{pH}$ of the mixture decreased from nearly neutral to acidic range (5.2-6.9). Intermittent aeration regime (between 0.04 and $0.08 \mathrm{~L} \cdot \mathrm{min}^{-1} \cdot \mathrm{Kg}_{\mathrm{VM}}{ }^{-1}$ ) was proposed to attain pathogen-eradication (above $55{ }^{\circ} \mathrm{C}$ for three days) and odor control without volatilizing significant amount of the organic matter content in the mixture. Chemical composition changes during a 63-day composting experiment of swine manure blended with sawdust in a pile composting were investigated [36]. There was a rapid decline in organic- $C$ from 45 to $36 \%$ within the first 14 days, followed by a slow decline in the remaining time, totaling a $10 \%$ drop in the process. Swine manure was also found to lose up to $72 \%$ of its organic $\mathrm{C}$ and $60 \%$ of the total $\mathrm{N}$ through emissions as part of the decomposition and mineralization stages [37]. Carbon dioxide and ammonia volatilization remain the primary causes of the losses. Various greenhouse gas (GHG) emissions from unturned and turned compost piles of manure and bedding material mixtures were monitored for over 80 days [38]. Higher GHG emissions were reported from turned piles $\left(1.98 \mathrm{~kg} \mathrm{CO}_{2}\right.$-eq $\left.\mathrm{kg}_{\mathrm{VSdegraded}}{ }^{-1}\right)$, in comparison to unturned ones which reported to be $1.55 \mathrm{~kg}_{\mathrm{CO} 2-\mathrm{eq}} \cdot \mathrm{kg}_{\mathrm{VSdegraded}}{ }^{-1} \cdot \mathrm{CO}_{2}$ emissions comprised the bulk of GHG emissions (75-80\%), followed by $\mathrm{CH}_{4}$, at $18-21 \%$, then finally $\mathrm{N}_{2} \mathrm{O}$ at $2-4 \%$.

Table 2. Typical composition of liquid and solid swine manure [38].

\begin{tabular}{|c|c|c|c|c|c|}
\hline Manure & $\begin{array}{c}\text { Dry Matter } \\
\left(\mathrm{g} \cdot \mathrm{kg}^{-1}\right)\end{array}$ & $\begin{array}{c}\text { Organic C } \\
\left(\mathrm{g} \cdot \mathrm{kg}^{-1}\right)\end{array}$ & $\begin{array}{c}\text { Total N } \\
\left(\mathrm{g} \cdot \mathrm{kg}^{-1}\right)\end{array}$ & $\begin{array}{c}\mathrm{NH}_{4}-\mathrm{N} \\
\left(\mathrm{g} \cdot \mathrm{kg}^{-1}\right)\end{array}$ & $\mathrm{pH}$ \\
\hline Liquid & $4.9-152$ & $1.0-65$ & $0.6-7.8$ & $0.3-6.6$ & $6.7-8.9$ \\
\hline Solid & $150-330$ & $42-132$ & 3.5-11 & $0.5-6.0$ & 8.1 \\
\hline
\end{tabular}

\subsection{Swine Manure Anaerobic Digestion}

Anaerobic digestion of manure provides a method to treat animal waste by allowing microorganisms to digest the feedstock. This process produces biogas (with similarity to natural gas) suitable for energy production through burning, internal combustion engines, and gas turbines. The solids produced after the digestion process can be used as fertilizer or bedding for farm animals. About 200 anaerobic digesters were installed at dairy farms through the USA as a reaction to the energy deficient in the early 1970s. Several of these systems shut down or failed after just a few years of operation. In 2014, about 260 anaerobic digesters were operational in USA farms with only 39 digesters operational in swine farms according to data compiled by AgStar (AgStar Financial Services, Mankato, MN, USA), an EPA program to promote $\mathrm{CH}_{4}$ mitigation projects in the livestock sector [39]. Anaerobic digestion process works efficiently with dairy and beef manures, although research continue to improve the process for swine and other animals. With enhancements in anaerobic digester equipment, as well as a better understanding of the method, there was a recovery of anaerobic digesters being installed on large dairy farms starting in the late 1990s and continuing to this day.

In mostly confined swine houses, anaerobic digestion occurs in the manure collection pits, and in the last storage lagoons. To activate specific bacterial and microbial communities that digest the organic matter, this process requires anaerobic conditions (oxygen-free). The composite manure substrate is converted to an effluent of degraded humic acids, and a mixture of gases $\left(\mathrm{CH}_{4}, \mathrm{CO}_{2}, \mathrm{NH}_{3}\right.$, and $\left.\mathrm{N}_{2} \mathrm{O}\right)$ by anaerobic bacteria. This process has been understood on USA swine farms in manure collection lagoons before the annual, or bi-annual, land application. However, most of these lagoons are not covered, meaning that the process only occurs within certain anaerobic sections of the lagoon.

Most farms do not actively flush or collect volatilized gaseous species resulting from digestion, making these gases a prominent source of greenhouse gas (GHG) emissions in agriculture. For instance, between 1990 and $2011 \mathrm{CH}_{4}$ and $\mathrm{N}_{2} \mathrm{O}$ emissions from USA manure management were found to have increased from 31.5 to $52.0 \mathrm{Tg}_{\mathrm{CO} 2 \text {-eq, }}$ and from $14.4 \mathrm{Tg}_{\mathrm{CO} 2 \text {-eq }}$ to $18.0 \mathrm{Tg}_{\mathrm{CO} 2 \text {-eq, }}$, respectively [40]. 
These increases were credited, to the increase in the size of production units, and the spread of liquid handling and storage in dairy and swine production. Only a handful of USA farms have active digestion processes with covered anaerobic digesters where temperature, $\mathrm{pH}$, and organic matter loading are controlled for purposes of biogas generation for energy or heating or both.

As shown in Figure 1, anaerobic digestion is a sequential process with different groups of bacteria carrying out different tasks to fully digest the biological substrate. After hydrolysis of soluble components, complex organic acids are transformed into volatile fatty acids (VFAs) by acidogenic bacteria. The VFAs are then transformed to acetate by acetogenic bacteria [41]. The VFDs were shown to decrease the $\mathrm{pH}$ of the mixture, thus damaging the $\mathrm{pH}$-sensitive acetogenic and methanogenic bacteria. After inducing perturbation (changes in hydraulic retention time of substrate, temperature, and organic matter loading) to the anaerobic digestion of a cattle-swine manure mixture, changes in the VFAs concentration were reported [42]. Ammonia $\left(\mathrm{NH}_{3}\right)$ as a by-product of the acidogenesis was found to have an inhibitory effect on the digestion process. For instance, anaerobic digestion literature indicates that 1.7 to $14 \mathrm{~g} \cdot \mathrm{L}^{-1}$ total ammonium nitrogen (TAN), can lower $\mathrm{CH}_{4}$ production by $50 \%$ [43]. Swine manure was proven to be challenging in anaerobic digestion studies, due to its high $\mathrm{NH}_{4}-\mathrm{N}$ and sulfide contents $[44,45]$. Carbon-rich sources such as crop residue, glucose or glycerol are added to the swine manure to adjust the starting $\mathrm{C} / \mathrm{N}$ ratio and to elucidate this challenge. Investigation of crop residue additive (wheat straw, corn stalks, and oat straw) and the $\mathrm{C} / \mathrm{N}$ ratio $(16,20$, and 25) on the gas yield from anaerobic digestion of swine waste was carried out [46]. There was a definite correlation between increasing the $\mathrm{C} / \mathrm{N}$ ratio and the yields of both the $\mathrm{CH}_{4}$ and the total biogas. Wheat straw blends yielded significantly lower $\mathrm{CH}_{4}$ and biogas at all $\mathrm{C} / \mathrm{N}$ levels when compared to corn stalks and oat straw blends. A better explanation for the occurrence is that wheat straw contained much higher lignin content, which is inaccessible to most digestive bacteria, in comparison to the other crop residues.

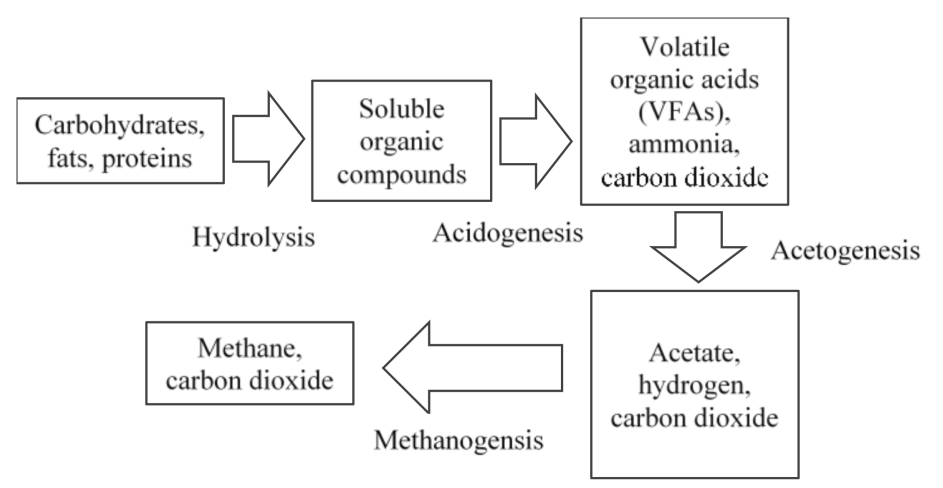

Figure 1. Biomass transformation with the various stages of anaerobic digestion [47].

As mentioned earlier, there are two temperature ranges for achieving anaerobic digestion process namely mesophilic and thermophilic. The removal of chemical oxygen demand (COD), biogas production, and $\mathrm{CH}_{4}$ production disparity effected by mesophilic and thermophilic anaerobic digestion were studied [48]. Only minimal differences in COD reduction, $63 \%$ versus $67 \%$, and volatile solids (VS) reduction of $64 \%$ versus $65 \%$, were observed between mesophilic and thermophilic conditions, respectively. However, $\mathrm{CH}_{4}$ productions were lower in thermophilic conditions compared to mesophilic conditions of 3.3 versus $3.5 \mathrm{~L}_{\text {reactor volume }}{ }^{-1}$ day $^{-1}$, respectively. On the other hand, biogas yields and $\mathrm{CH}_{4}$ concentrations in the biogas under thermophilic conditions were $494-611 \mathrm{~L} \cdot \mathrm{kg}_{\mathrm{VS}}{ }^{-1}$ (vs denotes to volatile solids) and 59.8-61.7\%, which were higher than those under mesophilic conditions $315-419 \mathrm{~L} \cdot \mathrm{kg}_{\mathrm{VS}}{ }^{-1}$ and $56.9-57.7 \%$, for the anaerobic digestion of three different maize varieties [49]. Thermophilic digestion increased the metabolism of bacterial communities but resulted in a buildup of VFA, in case of high-protein and urea substrates, which resulted in an accumulation of 
$\mathrm{NH}_{3}$ [50]. Increases in free $\mathrm{NH}_{3}$ concentration $\left(0.75-2.6 \mathrm{gm}_{\mathrm{N}} \cdot \mathrm{L}^{-1}\right)$, VFA accumulation $\left(\mathrm{gm}_{\text {acetate }} \mathrm{L}^{-1}\right)$ and a decrease in methane yield $\left(188-220 \mathrm{~mL}_{\mathrm{CH} 4} \mathrm{gm}_{\mathrm{VS}}{ }^{-1}\right)$ were observed with temperature increases in a study of swine manure anaerobic digestion [46]. There arises a critical need for continual monitoring and control of the swine manure anaerobic digestion due to the difficulty of the process and reluctance of stakeholders to adopt the technology. Furthermore, challenges arise due to the toxic effect of the liberated $\mathrm{NH}_{3}$ in the digestion of nitrogen-rich sludge, such as swine manure [51].

\subsection{Swine Manure Biodrying (Partial Composting)}

The majority of the manure thermochemical conversion technologies or applications require manure drying to facilitate both transportation and conversion. Animal waste drying is a challenging procedure given its relatively low heating value of $19.7 \mathrm{MJ} \cdot \mathrm{kg}^{-1}$ on a dry basis [52]. Table 3 shows the heating value of swine manure as well as both conventional fossil fuels, and different biomasses.

Table 3. Typical higher heating values $\left(\mathrm{HHV}, \mathrm{MJ} \cdot \mathrm{kg}^{-1}\right)$ for various feedstocks $[53,54]$.

\begin{tabular}{cc}
\hline Feedstock & HHV (MJ·kg \\
\hline $\mathbf{1})$-Dry Basis \\
\hline Bituminous coal & 31.60 \\
Peat & 21.22 \\
Cellulose & 17.30 \\
Lignin & 26.70 \\
Poplar wood chips & 20.75 \\
Oil shale & 12.44 \\
Wheat straw & 17.55 \\
Corn stover & 18.10 \\
Rice straw & 15.95 \\
Poultry litter & 17.14 \\
Cattle manure & 17.36 \\
Swine manure & 19.70 \\
\hline
\end{tabular}

Manure drying is the leading obstacle to the broader application of thermochemical conversion due to the lack of economic manure drying. Biodrying has become a remedy to this obstacle. Biodrying is a biological process by which biodegradable waste is quickly heated through initial stages of biodegradability to remove excess moisture. The manure biodrying technique is a physical-biological treatment of organic feedstock generating heat from exothermic reactions, along with excess aeration, to volatilize most of the moisture yielding minimum carbon conversion. Except for the required aeration rates, biodrying and composting procedures are similar in their operating parameters. Biodrying operating parameters including pile temperature, reactor configuration, and aeration rate have been studied numerously. Adani et al. [55] carried out studies on the effects of temperature of biomass on the biodrying of urban solid waste. They adjusted aeration by setting three different temperature levels; 70,60 and $45^{\circ} \mathrm{C}$. They attributed high temperatures with favorable biomass degradation, more stable high moisture material with low energy content. In previous studies [56,57] researchers indicated that elevated temperatures facilitated microbial activities until a threshold of $55-60{ }^{\circ} \mathrm{C}$, beyond which microbial activity and heat generation diminished. Sadaka and Ahn [57] biodried swine manure-corn stover mixture. They reported that with no external heat provided to swine manure-corn stover mixture, about $50 \%$ reduction of the initial water content was achieved after biodrying for 2-4 weeks. A thermophilic temperature of $60^{\circ} \mathrm{C}$ was attained after four days for swine manure. Biodrying did not significantly affect the biodegradability of the mixture as measured by volatile solids and heating value reductions.

The deliberation is presently continuing regarding the determination of suitable aeration levels for both composting and biodrying. Various composting studies have recommended various aeration rates. $\mathrm{Li}$ et al. [58] reported that several aeration rates on dairy manure composting indicate that $0.25 \mathrm{~L} \cdot \mathrm{min}^{-1} \cdot \mathrm{kg}^{-1}$ volatile matter $(\mathrm{VM})$ achieved the highest temperature and kept it for the longest 
retention time, with lowest emissions of odorous gases. Hong et al. [59] also mentioned that the maximum degradation rate in dairy manure composting occurs with an air flow rate between 0.87 and $1.87 \mathrm{~L} \cdot \mathrm{min}^{-1} \cdot \mathrm{kg}^{-1}$ volatile matter. Gao et al. [60] investigated the effects of three aeration levels; $0.3,0.5$ and $0.7 \mathrm{~L} \cdot \mathrm{min}^{-1} \cdot \mathrm{kg}^{-1}$ volatile matter on the composting of poultry manure and sawdust. They found that the best quality of composted manure (regarding maturity and stability) was under the air flow rate of $0.5 \mathrm{~L} \cdot \mathrm{min}^{-1} \cdot \mathrm{kg}^{-1}$ volatile matter. Aeration levels for the biodrying process are recommended by few studies [61]. Consequently, there is a need to assess the effects of various aeration levels on the biodrying process of swine manure mixed with crop residues.

\subsection{Challenges Associated with Swine Manure Biological Conversion}

It is often quite challenging to operate biological conversion systems due to the complexity and interdependencies in the process. There are several attainment stories of biological conversion systems that have helped producers in meeting their goal of converting swine manure to value-added products. On the other hand, some biological conversion systems failed despite the enhancements of the biological conversion techniques. These failures can be attributed to the following causes:

- Poor design and equipment selection: Design and equipment selection for biological conversion systems can include decisions related to the manure pumping and conveyance systems, the gas cleaning and electrical generation equipment. Therefore, it is essential that the proper technology and equipment be selected. A failure of any one of these system components can result in operation failure, reduced revenue generation or added capital costs to replace faulty equipment.

- Lack of appropriate technical expertise: There is a lack of technical expertise in managing biological conversion systems in many cases due to the complexity of manure treatment systems. Although animal farmers routinely manage other complex systems, and training programs on biological conversion systems are available, there is a need to enhance the manure management skills to be able to sustain steady-state operations.

- Lack of system maintenance: Biological conversion systems need to be well maintained. Accordingly, producers need to dedicate some time and costs for maintaining these systems to avoid downtime.

- Lack of commitment by the operator: Given the seasonal nature of farming, there can be times of the year when the biological conversion systems may not receive the required attention and the careful maintenance. Again, this can be associated with the view that these systems are not an essential business function of the animal farm.

\section{Thermochemical Conversion of Swine Manure}

Thermochemical conversion, mainly combustion, remains the oldest known thermal technique to convert organic and biological residues to heat. Thermochemical conversion techniques include combustion, gasification, pyrolysis, liquefaction, and carbonization. Thermochemical processes utilize elevated temperatures, at different ranges for each process, aided by an oxidative or an inert agent. These processes target energy production or destruction of hazardous wastes.

\subsection{Swine Manure Combustion}

Combustion enabled people to utilize energy contained in organic matter for heating and cooking. Embedded in the hydrocarbon bonds, i.e., coal, petroleum and natural gas, and biomass, i.e., forest, crop or livestock residue, is fossilized energy which can be released under oxidative conditions using heat. A direct correlation can be drawn between the embedded energy and hydrogen $(\mathrm{H})$, carbon $(\mathrm{C})$, and oxygen $(\mathrm{O})$, sulfur $(\mathrm{S})$ and ash contents of the feedstock. Feedstock heating value is the primary characteristic that determines whether it could be logistically and economically used as an energy source. The heating value of common solid fuels is highly dependent on its characteristics and composition [62]. Various models were developed to forecast the heating value of biomass 
from its composition $(\mathrm{C}, \mathrm{H}, \mathrm{N}, \mathrm{O}, \mathrm{S}$, and ash); proximate analysis (volatile matter, and fixed carbon), or summative analysis (cellulose, hemicellulose, and lignin) [63]. Ultimate analysis models: C, H, S, N, $\mathrm{O}$, and Ash proved to be the most accurate in predicting higher heating values in biomass. Channiwala and Parikh [64] developed a correlation to estimate the HHV (MJ. $\mathrm{kg}^{-1}$ ) of solid, liquid and gaseous fuels as follows:

$$
\mathrm{HHV}=0.3491 \mathrm{C}+1.1783 \mathrm{H}+0.1050 \mathrm{~S}-0.1034 \mathrm{O}-0.0151 \mathrm{~N}-0.0211 \mathrm{Ash}
$$

where

$\mathrm{C}, \mathrm{H}, \mathrm{S}, \mathrm{O}, \mathrm{N}$, and Ash represent the elemental analysis of the feedstock.

$\mathrm{HHV}$ is the higher heating value, $\mathrm{MJ} \cdot \mathrm{kg}^{-1}$.

It should be mentioned that HHV is the energy released upon oxidation of unit mass of the feedstock taking into consideration the enthalpy of vaporization for the generated water, whereas LHV accounts only the oxidation enthalpy. The correlation [65] below can be used to calculate one from the other, in units of $\mathrm{MJ} \cdot \mathrm{kg}^{-1}$ :

$$
\mathrm{HHV}=\mathrm{LHV}+21.978 \times \mathrm{H}
$$

where:

$\mathrm{H}$ is the hydrogen weight fraction in the sample.

$\mathrm{LHV}$ is the lower heating value, $\mathrm{MJ} \cdot \mathrm{kg}^{-1}$.

The combustion process is an accumulation of sequential steps of drying, pyrolysis (devolatilization), gasification, char combustion, and gas-phase oxidation. The biomass moisture evaporates at rates dependent on the particle size, and the vapor pressure in the surrounding space under atmospheric pressure $(101.3 \mathrm{kPa})$ and at temperatures above $100^{\circ} \mathrm{C}$. Volatile organic species pyrolysis takes place at temperatures between $250{ }^{\circ} \mathrm{C}$ and $500{ }^{\circ} \mathrm{C}$. Depending on the biomass type, and based on the size of biomass particles this range varies accordingly. Exothermic mixed reactions (gas-solid gasification, and char combustion) and exothermic homogenous reactions (gasification, and gas combustion) take place at higher temperatures between $600{ }^{\circ} \mathrm{C}$ and $1200{ }^{\circ} \mathrm{C}$. Thermal energy and flue gas $\left(\mathrm{CO}_{2}, \mathrm{H}_{2} \mathrm{O}, \mathrm{NO}_{2}\right.$, and $\left.\mathrm{SO}_{2}\right)$, in addition to an inert ash residue, are released by these reactions. An organic molecule's embedded energy is the enthalpy of the complete oxidation of its hydrocarbons, into oxides and water.

Majority of incinerators used with biomass are grate, or fluidized-bed systems. They are more flexible to the fuel type, suspension burners which only allow for co-firing biomass at specific ratios ( $25 \%$ by energy share) with particular moisture, ash content and particle size prerequisites [66].

Combustion technology is effective in reducing animal manure volume and concentrating nutrients. Park et al. [67] evaluated the feasibility of using solids separated from swine wastewater treatment practice as a fuel source for heat production. Proximate analysis of the solid recovered from the swine wastewater after flocculation with organic polymer showed that the high heating value and the moisture content were $22.3 \mathrm{MJ} \cdot \mathrm{kg}^{-1}$ and $15.38 \%$, respectively. The combustion efficiency of the solids was found to be in the range of $95 \%$ and $98 \%$ with varied temperatures. Based on their results they recommended that solid separated from swine manure can be used as an alternate source of fuel.

Swine manure, coal, and their co-combustion (10\% dry weight of manure) were studied by simultaneous TG/MS dynamic runs [68]. Furthermore, the non-isothermal kinetic analysis presented that the Arrhenius activation energy parallel to the combustion of the blend $\left(125.8-138.9 \mathrm{~kJ} \cdot \mathrm{mol}^{-1}\right)$ was slightly higher than that of manure $\left(106.4-114.4 \mathrm{~kJ} \cdot \mathrm{mol}^{-1}\right)$ or coal $\left(107.0-119.6 \mathrm{~kJ} \cdot \mathrm{mol}^{-1}\right)$. The valorization of three different manure samples through pyrolysis and combustion processes was evaluated [69]. Dairy manure and swine manure were biologically pretreated by anaerobic digestion and biodrying processes, respectively. Thermal behavior of manure samples was studied using thermogravimetric analysis coupled with mass spectrometry. These researchers reported 
that the processes could be divided into four stages to include dehydration, devolatilization, char transformation and chemical matter decomposition. They attributed the differences among the samples to their different composition and pretreatment. Combustion characteristics of bio-oil derived from swine manure were examined using thermogravimetry techniques [70]. The results designated that the combustion processes of bio-oil happened in three stages, namely the water and the lighter compound evaporation, i.e., the release of the volatile compounds, ignition, and burning of the more massive compounds (central carbon), and finally decomposition of the carbonate compounds.

Various biomasses lean towards the slagging and fueling in the combustion reactors. Several indices were developed to correlate the composition and alkaline minerals to the slagging tendency. Determining the weight of alkali oxides (potassium and sodium oxides) per unit energy (heat) in the fuels used is among the standard measures to monitor slagging and fouling upon co-firing agricultural and biomass residue. The upper limit for alkali levels in fuel is $0.17 \mathrm{~kg} \cdot \mathrm{GJ}^{-1}$ to minimize the chance of slagging and fueling. Biomass $\mathrm{S}$ and $\mathrm{Cl}$ were influential in fouling and minerals deposition mostly because of the formation of alkali sulfates and chlorides that condensed on fly-ash, gas exits and downstream. On the other hand, the interaction of K and P with Si and Ca was responsible for the formation of agglomerates in fluidized bed combustors [71].

Combustion of animal manure produces ash that has concentrated nutrients. Komiyama et al. [71] tested the chemical characteristics of ashes from three manure types namely cattle, poultry, and swine manure. The concentration of $\mathrm{P}$ and $\mathrm{K}$ did not change in cattle and layer manure due to the existence of Si and Ca. However, the concentration of P increased by 3.6 and 4.6 folds for swine and broiler manure, respectively as compared to the original materials. In another study, after incineration at $700{ }^{\circ} \mathrm{C}$, the resultant manure ashes were investigated [72]. High $\mathrm{pH}(>10)$, increased the concentration of $\mathrm{P}, \mathrm{K}$, and heavier metals like zinc $(\mathrm{Zn})$, copper $(\mathrm{Cu})$ and manganese $(\mathrm{Mn})$ for all ashes. $\mathrm{N}$ was never detected in the manure. Swine manure ashes had the highest $P$ concentration in ash residue, around $10-12 \%$. These $\mathrm{P}$ levels are close to those in phosphate rocks, regularly used as soil amendment. Combustion temperature impact of solids on plant-available $\mathrm{P}$ in the swine manure ash was investigated [73]. An insoluble crystalline form of phosphorous (hydroxyapatite, $\mathrm{Ca}_{5}\left(\mathrm{PO}_{4}\right)_{3}(\mathrm{OH})$ ) was formed at temperatures of $700{ }^{\circ} \mathrm{C}$ and above. Therefore, to retain the functionality of ash-bound $\mathrm{P}$, low-temperature combustion or gasification technologies $\left(400-700^{\circ} \mathrm{C}\right)$ were recommended.

\subsection{Swine Manure Gasification}

During gasification, that takes place in a starved oxygen environment, biomass particles undergo drying, devolatilization, solid-gas and gas-phase reactions that produce producer gas, char, and a small fraction of condensable [74]. Gasification primary objective is the production of an energy-rich blend of gases called "producer gas" that could be combusted in boilers, internal combustion (IC) engines or gas turbines. Producer gas contains carbon dioxide $\left(\mathrm{CO}_{2}\right)$ carbon monoxide $(\mathrm{CO})$, hydrogen $\left(\mathrm{H}_{2}\right)$, methane $\left(\mathrm{CH}_{4}\right)$ and nitrogen $\left(\mathrm{N}_{2}\right)$ typically. Gasification takes place under temperature levels of $700{ }^{\circ} \mathrm{C}$ and $1000{ }^{\circ} \mathrm{C}$, which is often lower than those of combustion. However, the type of feedstock is used to determine the exact gasification temperature. Coal, because of its low volatile matter content and low reactivity, has higher reaction temperatures than biomass. The gasification reactions commence after the biomass feedstock undergoes drying and devolatilization. Biomass has a much higher volatile matter content (around $80 \%$ of dry weight) and a more reactive char because of the catalytic effect of the ash minerals. The overall biomass gasification reaction in the air and steam environment can be represented by Equation (4), which proceeds with several gasification reactions as shown in the subsequent equations $[75,76]$ :

$$
\begin{gathered}
\text { Biomass }\left(\mathrm{CH}_{\mathrm{x}} \mathrm{O}_{\mathrm{y}}\right)+\text { Air }+ \text { Steam }=\mathrm{CO}_{2}+\mathrm{CO}+\mathrm{CH}_{4}+\mathrm{H}_{2}+ \\
\left.\mathrm{N}_{2}+\mathrm{H}_{2} \mathrm{O} \text { (unreacted steam }\right)+ \text { tar }+ \text { Char }
\end{gathered}
$$


Combustion reactions:

$$
\mathrm{CO}+1 / 2 \mathrm{O}_{2}=\mathrm{CO}_{2}-283 \mathrm{MJ} \cdot \mathrm{kmol}^{-1}
$$

Fischer-Tropsch reaction:

$$
\mathrm{C}+2 \mathrm{H}_{2}=\left(\mathrm{CH}_{2}\right)+\mathrm{H}_{2} \mathrm{O}-165 \mathrm{MJ} \cdot \mathrm{kmol}^{-1}
$$

The Boudouard reaction:

$$
\mathrm{C}+\mathrm{CO}_{2}=2 \mathrm{CO}+172 \mathrm{MJ} \cdot \mathrm{kmol}^{-1}
$$

The water gas reaction:

$$
\mathrm{C}+\mathrm{H}_{2} \mathrm{O}=\mathrm{CO}+\mathrm{H}_{2}+131 \mathrm{MJ} \cdot \mathrm{kmol}^{-1}
$$

The methanation reaction:

$$
\mathrm{C}+2 \mathrm{H}_{2}=\mathrm{CH}_{4}-75 \mathrm{MJ} \cdot \mathrm{kmol}^{-1}
$$

Methane steam reforming:

$$
\mathrm{CH}_{4}+\mathrm{H}_{2} \mathrm{O}=\mathrm{CO}+3 \mathrm{H}_{2}+260 \mathrm{MJ} \cdot \mathrm{kmol}^{-1}
$$

Additionally, some other elements, $\mathrm{N}$ and $\mathrm{S}$, are liberated together with producer gas in the form of ammonia $\left(\mathrm{NH}_{3}\right)$, hydrogen sulfide $\left(\mathrm{H}_{2} \mathrm{~S}\right)$, hydrogen cyanide $(\mathrm{HCN})$, and nitrous oxides $\left(\mathrm{NO}_{\mathrm{x}}\right)$.The reaction temperature, heating mode (auto-thermal or externally heated), amount of oxidant present (typically oxygen) in the reaction volume per mole of biomass, use of a catalyst, physical and chemical characteristics of the biomass particles, and the type of gasification system are the key factors that influence gasification efficiency.

Pure oxygen, steam, carbon dioxide or blends of these oxidants can be used as the gasifying agent apart from the atmospheric air [77,78]. Energy-intensive oxidants such as pure oxygen or steam should only be used with high calorific value feedstock according to thermodynamic efficiency of the conversion. The use of air as the gasifying agent means the dilution of the product gas with nitrogen from the air $(78.09 \mathrm{vol} . \%)$. It should be mentioned that the gasification process can be achieved without supplying an external oxidant given that most biomasses contain $\mathrm{O}_{2}$ as part of their structures. There is a requirement for an external source of heat when no oxidizing agent is supplied because all devolatilization reactions: the water-gas reaction, and the Boudouard reaction are endothermic. On the other hand, supplying an oxidizing agent could eliminate the need for external heat beyond the startup (autothermal mode) because the exothermic reactions, full- or partial-oxidation reactions, can sustain the conversion.

Extensive research has gone into biomass gasification leading to commercial adoptions in different gasifier configurations. Gasification platforms resemble combustion units as relates to feeding mechanisms and reactor types. These systems are classified as a fixed bed, fluidized bed, and plasma gasifiers. In fixed bed gasifiers, biomass feed is fed into metered or gated entrance moving gradually, by gravity, across the various reaction zones. The feedstock is incrementally fed in, as part of the stack is reacted away into producer gas, char, and tars. The stages of the gasification process of drying, devolatilization or pyrolysis, char gasification (Reduction) and combustion proceed within distinct stratified zones in the biomass stack. Dependent on the thermodynamics of reaction taking place in each zone, temperatures inside a fixed-bed gasifier are also stratified. Downdraft, updraft, and cross draft systems represent fixed-bed gasifier's examples based on the relative movement of the producer gas concerning the feedstock. Downdraft gasifiers are the most common among fixed bed systems due to their ease of operation, and the superior quality of producer gas (low tar and condensable) [79]. 
Tar and condensable are deposited on low-temperature surfaces, typically downstream, causing blockages and considerable pressure drops during gasification process. Additionally, tar content corrodes the combustion chamber and forms undesirable deposition applications where the producer gas is directly fired. The majority of commercial gasification systems (75\%) are downdraft gasifiers with updraft systems accounting for only $2.5 \%$ [80]. In a laboratory-scale gasifier, agglomeration (formation of an ash-layer as well as condensation in upper parts of a countercurrent/updraft) was reported with nutshells, and olive husks gasification [81].

Fluidized-bed gasification is a relatively newer model of conversion comparatively. Fluidized beds are rapid and efficient options that are also suitable for up-scaling. They consist of an inert, thermally stable media like silica, olivine, or alumina particles, blended at times with specialty catalysts for tar reforming. This inert media serves as the heat-transfer medium that facilitates conversion as the feedstock is fed into the reactor. The heat transfer is higher than in fixed bed reactors due to the fluidization of the biomass-bed material mixture increasing the contact between hot media and ambient biomass particles. Compared to fixed-bed reactors, the fluidized bed does not have thermal stratification or distinct conversion zones (isothermal conditions), helping it achieve steady-state operation faster. In fact, both the drying and the devolatilization stages are assumed to be instantaneous once the biomass enters the reactor bed. Circulating fluidized bed systems are also utilized in biomass conversion as well as a bubbling fluidized system described above. Unlike a bubbling fluidized bed unit, this system consists of two reactors connected in series to form a closed loop for the solids. Fluidization velocities in this system tend to be higher than in bubbling fluidization. By using gravity, char particles are entrained out of the first reactor and are allowed to react in the secondary-bed with the residues collected and circulated back to the main reactor bed.

Plasma gasification is an allothermal process occurring when organic matter is exposed to an extreme thermal practice using a plasma torch to produce syngas. Because feedstock varies in physical form, moisture content, ash content, and chemical composition, a plasma reactor must be designed to meet these differences. Therefore, a single plasma reactor design would not apply for all waste treatment cases [82]. Rajasekhar et al. [83] described plasma gasification as involving gases such as air, oxygen, nitrogen or noble gases, and this produces exceptionally high temperatures, which depolymerizes feedstock to individual atoms such as carbon, hydrogen, and oxygen. These atoms react with each other to form high-quality syngas. At these high temperatures, the inorganic part (metals, glass, silicates) extrudes from the bottom of the reactor and forms an inert, non-leachable vitrified slag that can be landfilled [84,85]. Campos et al. [85] reported that by utilizing plasma arc technology, it was possible to generate $816 \mathrm{kWh}$ per ton of municipal solid waste (MSW); this is a higher energy producer than incineration, pyrolysis or conventional gasification. Plasma gasification has several advantages including better environmental benefits through lower emissions, vitrified slag has numerous usages compared to ash, metals, and slag from gasification, disposal of hazardous wastes (dioxins), higher gross energy recovery resulting from complete decomposition to the elemental level, and smaller installation size increasing process controllability $[86,87]$. There are some disadvantages related to plasma gasification including lack of reliability, high energy consumption, high consumption of electrical energy, which is economically costly, and high initial investment [88].

Biomass waste such as swine manure separated solids (SMSS), with the molecular formula $\mathrm{CH}_{1.69} \mathrm{O}_{0.5}$, is shown on the $\mathrm{C}-\mathrm{H}-\mathrm{O}$ triangular (ternary) diagram (see Figure 2) [89]. The area around dotted lines shows an equilibrium state between gaseous species and solid carbon (i.e., gasification region). Below the gasification, the region is fully oxidized carbon gaseous species while within the region above, only solid carbon exists. 


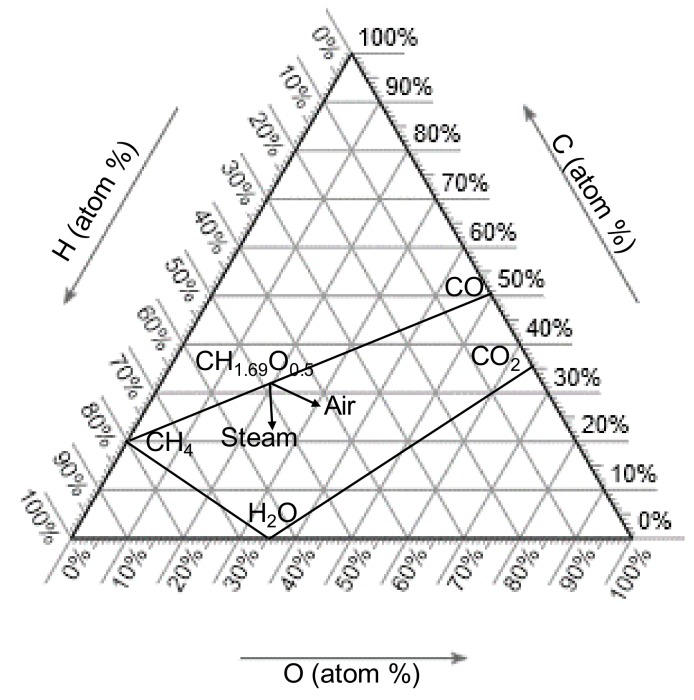

Figure 2. A ternary $\mathrm{C}-\mathrm{H}-\mathrm{O}$ plot is illustrating biomass waste gasification using either air or steam as the gasification medium.

The impact of gasification variables, including, equivalence ratio (ER), bed temperature, freeboard temperature, and the existence of a tar-reforming stimulus (calcined dolomites: $\mathrm{MgO}$. $\mathrm{CaO}$ ) on quality of producer gas was evaluated [90]. The ER remained the essential factor in determining the quality of the producer gas and the yield of tars generated. Increasing the ER from 0.18 to 0.41 and from $7.2 \mathrm{gm} \mathrm{Nm}^{-3}$ to $4.6 \mathrm{gm} \mathrm{Nm}^{-3}\left(\mathrm{Nm}^{3}\right.$ is a cubic meter normalized to standard temperature and pressure conditions, $25^{\circ} \mathrm{C}$ and $101.3 \mathrm{kPa}$ ) caused a drop in the tar-to-producer gas ratio [91]. Fixed bed gasifiers produce higher tar yields, representing between $12 \mathrm{wt}$. \% and $20 \mathrm{wt} . \%$ of the carbon in the biomass, compared to tar in fluidized-bed systems which represent $4.3 \mathrm{wt}$. \% of biomass carbon at $750{ }^{\circ} \mathrm{C}$ [92]. For optimal conversion, ER values between 0.25 and 0.30 were recommended. Temperature influence on gasification of feedlot cattle manure in a fluidized bed system was evaluated with the temperatures varied between $627^{\circ} \mathrm{C}$ and $727^{\circ} \mathrm{C}$. Burner gas (generated from propane-air burning), was used as the fluidizing-gasifying agent. The producer gas yield reached $0.54 \mathrm{Nm}^{3} \cdot \mathrm{kg}^{-1}$ with $19.53 \mathrm{MJ} \cdot \mathrm{Nm}^{-3}$ higher heating value. Burner gas as the gasifying agent has undoubtedly augmented the producer gas with combustion hydrocarbons. There was a $38.7 \%, 26.1 \%$ and $14.7 \%$ yield of $\mathrm{H}_{2}, \mathrm{CO}$, and $\mathrm{CH}_{4}$ energy-rich gases within the dry produced gas composition.

The producer gas can be purified and catalytically upgraded through the Fischer-Tropsch (F-T) process to produce liquid hydrocarbons or used in direct combustion on gas-burning systems [93]. A catalytic reforming step to adjust the ratio of hydrogen to carbon monoxide above unity, $\mathrm{H}_{2} / \mathrm{CO}>1$ and also to convert all $\mathrm{CH}_{4}$ and higher hydrocarbons to $\mathrm{CO}$ and $\mathrm{H}_{2}$ must be done to the producer gas [94]. As shown below in Equation (11), the Fischer-Tropsch reaction proceeds at a temperature between $200{ }^{\circ} \mathrm{C}$ and $250^{\circ} \mathrm{C}$, and pressures between 25 and 60 bars [95]. Liquid long hydrocarbon chains, $\mathrm{C} 5+$ are among the output products released along with gaseous fuel that can be suitable for power production in gas turbines. Adjusting the $\mathrm{H}_{2} / \mathrm{CO}$ to numbers around two can be done through the water gas shift reaction as shown in Equation (12):

$$
\begin{array}{cc}
\text { Fischer }- \text { Tropsch reaction } & \mathrm{CO}+2 \mathrm{H}_{2}=\mathrm{CH}_{2}+\mathrm{H}_{2} \mathrm{O}-165 \mathrm{MJ} \mathrm{kmol}^{-1} \\
\text { Water }- \text { gas shift reaction } & \mathrm{CO}+\mathrm{H}_{2} \mathrm{O}=\mathrm{CO}_{2}+\mathrm{H}_{2}-41 \mathrm{MJ} \mathrm{kmol}^{-1}
\end{array}
$$

Researchers assessed both dry and wet livestock manures gasification. Dry wastes alike poultry litter and feedlot manures can be treated directly via pyrolysis and air/steam gasification techniques. The solids produced from dairy and swine operations aqueous waste streams can be treated via wet 
gasification or direct liquefaction processes [96]. Current testing of the dry feedstocks, i.e., poultry litter and feedlot manure has been restricted to dry gasification systems using air as the oxidizing agent. Fixed-bed gasification yielded a low-heating value gas with an average HHV of $4.5 \mathrm{MJ} \cdot \mathrm{m}^{-3}$ for poultry litter (TS) $92.5 \mathrm{wt}$. \% and $4.1 \mathrm{MJ} \cdot \mathrm{m}^{-3}$ for feedlot manure with total solids of $92.4 \mathrm{wt}$. \%. The product gases contained a combustible portion consisting on average of $5.8 \% \mathrm{H}_{2}, 27.6 \% \mathrm{CO}$, and $1.0 \% \mathrm{CH}_{4}$. Unfortunately, the product gases were rigorously diluted with nitrogen, thus lessening the potential HHV by approximately $60 \%$. By blending the high-ash manure with a low-ash feedstock, as well as using acid washing, ash reduction is achievable. Evaluation of the ash minerals out of the biomass matrix can also be achieved efficiently by soaking biomass in diluted acid. In a swine and hen manures study, acid washing led to a drop in inorganic minerals ( $\mathrm{Fe}, \mathrm{Ca}, \mathrm{K}, \mathrm{Zn}, \mathrm{P}$, and $\mathrm{S}$ ) and a tentative drop in the char reactivity [97]. The reduced char reactivity was strongly correlated with low Ca concentration in acid-washed manures. Washing (soaking) and fractionation (removing $<1 \mathrm{~mm}$ particle size fraction), two approaches for ash reduction, were studied as pretreatment for peach stones gasification [98].

The critical challenge of manure gasification remains stratification of the reactive zones in fixed-bed systems because it results in the formation of hot spots and agglomerations. Investigations were done on the effects of mixing cow manure with sawdust, at different mixing ratios, on gasification efficiency in a downdraft gasifier [99]. Increasing the ratio of cow manure in the blends from 0 to $90 \%$ caused drops in the reduction zone temperatures, the producer gas heating value, and the conversion efficiency. The low conversion efficiency in cow manure was attributed to fixed carbon content within the manure being higher than sawdust translating to more endothermic char reduction reactions that cause a drop in the temperatures and the conversion efficiency. Pelletized poultry litter gasification was done in a commercial downdraft gasifier at temperatures between $825^{\circ} \mathrm{C}$ and $925^{\circ} \mathrm{C}$ [100]. Formation of clinkers (fused ash particles) in the reactor bed caused interruptions in gasification.

The presence of tar in the producer gas is a significant issue facing biomass gasification. Tar refers to mixtures of phenolic, and aromatic hydrocarbons formed during the devolatilization (pyrolysis) stage of gasification without sufficient decomposition inside the reactor to generate the targeted gases. Tar also refers to the subsidiary hydrocarbon compounds formed under high reaction rigor with higher molecular weights and higher aromaticity (polyaromatic). The volatilized organics formed during the pyrolysis stage are further digested by the increased gasification temperatures by either the gasifying agent or original oxygen and moisture (steam) in the feedstock. Persistence of tar in the produced gas can be attributed to the short residence time of vapor phase in high-temperature regions since most tar decomposition reactions are endothermic, as is the case with updraft gasifiers. In the absence of external oxidizing agents, volatiles undergoes subsidiary decomposition reactions at temperatures higher than $650{ }^{\circ} \mathrm{C}$ that increases permanent gases $\left(\mathrm{H}_{2}, \mathrm{CO}\right.$, and $\left.\mathrm{CO}_{2}\right)$ generation and decreases gravimetric tars [101]. By using mass spectrometry, tars were classified by their molecular masses into primary, secondary and tertiary tars [102]. With temperature increases, tars underwent both decomposition and repolymarization. This phenomenon explains the transformation of tars retrieved in biomass conversion from primary tars under common thermal conditions to secondary and tertiary tars under raised gasification temperatures, as shown in Table 4. Primary tars are comparatively more reactive and susceptible to thermal cracking in comparison to polycyclic aromatic hydrocarbons $(\mathrm{PAH})$ and tertiary tars [103]. The existence of heteroatoms $(\mathrm{O}, \mathrm{N})$ and side-groups $\left(\mathrm{OH}, \mathrm{CH}_{3}\right)$ in primary tars makes them more reactive than aromatic (ring) compounds. Free-radical reactions necessitated the primary thermal cracking mechanisms. The reactions take place through breakage of chemical bonds in a tar compound, the formation of free radicals that undergo propagation, isomerization and termination stages in which $\mathrm{H}_{2}$ and $\mathrm{CH}_{4}$ are liberated, and polyaromatic (tertiary) compounds are created. 
Table 4. Classes of tars formed during biomass gasification [102].

\begin{tabular}{llccc}
\hline \multirow{2}{*}{ Class } & \multicolumn{1}{c}{ Tar Class } \\
\cline { 2 - 5 } Compounds & $\begin{array}{l}\text { Levoglucosan, } \\
\text { hydroxyacetaldehyde, } \\
\text { furfurals, and } \\
\text { methoxyphenols }\end{array}$ & $\begin{array}{l}\text { Phenolics, } \\
\text { moreover, olefins }\end{array}$ & $\begin{array}{l}\text { Methyl acenaphthylene, } \\
\text { methylnaphthalene, } \\
\text { toluene and indene }\end{array}$ & $\begin{array}{l}\text { Benzene, naphthalene, } \\
\text { acenaphthylene, pyrene }\end{array}$ \\
\hline Temperature range & $500-800^{\circ} \mathrm{C}$ & $500-1000{ }^{\circ} \mathrm{C}$ & $700-1000{ }^{\circ} \mathrm{C}$ & $700{ }^{\circ} \mathrm{C} \geq 1000{ }^{\circ} \mathrm{C}$ \\
\hline
\end{tabular}

A study of biochar from manure gasification in a circulating fluidized bed (at $730{ }^{\circ} \mathrm{C}$ ), and acid-treated ash produced from manure combustion was done comparatively to test the use of both as phosphorous (P) fertilizers [104]. The two types of thermal residue (ashes and chars) yielded no discernible differences on $\mathrm{P}$ availability in the soil. Gasification char can be used as a phosphate fertilizer to augment soil $\mathrm{P}$ levels but not as a starter $\mathrm{P}$ fertilizer as indicated by the results.

\subsection{Swine Manure Pyrolysis}

Pyrolysis, as mentioned earlier, is the essential stage to both the combustion and gasification of biomass. During the pyrolysis stage, the solid biomass matrix undergoes thermal depolymerization producing gaseous species, volatile organic compounds, and causing a rearrangement of both the volatilized and solid components. Biomass pyrolysis is optimized to generate condensable organic compounds resembling naturally-occurring crude oil (often referred to as bio-oil or bio-crude) in addition to char and gaseous products. Pyrolysis does not need any oxidizing agent to facilitate the conversion, unlike combustion or gasification. It is necessary to rapidly remove the volatilized species from the reactor to the cold condensation unit. Quick removal and cooling of pyrolysis vapors (quenching) are crucial in avoiding further thermal decomposition of volatiles into permanent gases which equally minimizes the solid-vapor reactions that facilitate char formation.

Pyrolysis is classified as either slow or fast (flash) pyrolysis based on the process duration. Slow pyrolysis tends to provide high yields because of low heat transfer rates and longer residence times for both the solids and vapors. On the other hand, fast or flash pyrolysis has a high heating rate $\left(10^{3}-10^{4}{ }^{\circ} \mathrm{C} \cdot \mathrm{s}^{-1}\right)$, a residence time less than $2 \mathrm{~s}$, and rapid cooling of the volatile species which increases the condensable (bio-oil) yield [105]. Fluidized bed (bubbling and circulating), ablative (rotating cone, and vortex), and vacuum reactors were investigated in the context of fast pyrolysis $[106,107]$. Lignocellulosic biomass (mainly wood) products of fast pyrolysis average yields 60-75 wt. \% bio-oil, 15-25 wt. \% biochar, and 10-20 wt. \% non-condensable gases [108]. The main product in bio-oil is an acidic mixture ( $\mathrm{pH}$ between 2.5 and 3.5) of water (15-30 wt. \%) with a significant number of oxygenated hydrocarbons of different molecular weights. Acids, alcohols, aldehydes, ketones, aromatics, phenols and sugars are among more than 200 chemical species contained in bio-oils in varying concentrations depending on reaction conditions, and composition of original biomass [109,110]. Most woody and lignocellulosic feedstock pyrolysis reactions were grouped into cellulose, hemicellulose, and lignin pyrolysis reactions [111].

Phase separation of pyrolysis oil into water-rich and hydrocarbon-rich phases was achieved by adding surplus water to the bio-oil. Compared to liquid petroleum fuels, the oxygen content of bio-oil is quintessentially $45-50 \mathrm{wt}$. \% which, in combination with the water content in the bio-oil, result in low heating values of about $18-26 \mathrm{MJ} \cdot \mathrm{kg}^{-1}$.

Biomass bio-oil is both thermally and temporally unstable because of its high water content, acidity, and corrosiveness. Repolymarization and phase separation reactions between various products including acids, alcohols, and aldehydes through various mechanisms were outlined [112]. Shortly after production, bio-oil repolymarization and phase separation complicate storage and transportation. Therefore, bio-oil must be upgraded first to overcome these qualities that deem the bio-oil unfit for most applications. In the presence of catalysts, through hydrodeoxygenation (HDO), steam bio-oil upgrading can be achieved. One or two high stage pressures of catalytic hydrotreatment are useful for 
bio-oil upgrading [113]. The process involves the injection of hydrogen at an elevated pressure (more than 100 bar) within temperatures between $250{ }^{\circ} \mathrm{C}$ and $400{ }^{\circ} \mathrm{C}$ in the presence of catalysts (sulfide CoMo or NiMo). Inhibition of repolymarization reactions is a crucial challenge in bio-oil upgrading mainly caused by increased reaction severity (pressure and temperature). Additionally, plugging and coking (deactivation) caused by the failure of oxygen molecules to dissociate on the catalyst is a setback of larger bio-oil compounds. Under atmospheric conditions, zeolite catalysts facilitate bio-oil upgrading without the need for further hydrogen injection [114].

Syngas products $\left(\mathrm{CO}\right.$, and $\left.\mathrm{H}_{2}\right)$ have been produced through catalytic steam reforming of bio-oil products. As a means to expand the usefulness of the pyrolysis products, this technique has been investigated on bio-oil and model compounds such as phenol, acetone, and acetic acid [115]. The amount of energy spent in facilitating hydrogen production from bio-oil was equated to the energy necessary to reform natural gas into syngas products [116]. Steam reforming of bio-oil has challenges due to catalyst deactivation and coking [117].

Pyrolysis oil and gases have been investigated as fuel in compression (diesel) engines, turbines, and boilers. Hossain and Davies [118] reviewed the performance of pyrolysis products as fuel in internal compression engine. They reported various problems associated with pyrolysis oil as fuel, such as reduced ignition quality, corrosion, increased emissions and particulate matter in addition to low thermal efficiency. These challenges were attributed to the characteristics of the original feedstock, chemical and physical instability of the pyrolysis oil, and the high water and solids content. The change in bio-oil viscosity and composition with storage is a crucial barrier facing its utilization. Upgrading the pyrolysis oil, blending with diesel fuel, and modifying the engines showed improvement in the performance of pyrolysis oil as fuel. Indirect injection of pyrolysis oil in engines was recommended to ensure an even air-fuel mixture. Hossain et al. [119] evaluated pyrolysis oil blends ( $20 \%$ and $30 \%)$ with butanol, waste cooking oil, and diesel as fuel in compression engines. The tests showed the pyrolysis oil blends to reduce thermal brake efficiency by 3-7\% and produce lower $\mathrm{CO}$ emissions when compared to diesel fuel. Vihar et al. [120] utilized a tire pyrolysis oil as a fuel in a turbo-charged compression engine without blending or engine modification. They reported stable performance that is comparable to diesel fuel at full load. Heating the intake manifold was highlighted as a critical requirement to achieve stable operation using pyrolysis oil. They reported increased $\mathrm{NO}_{\mathrm{x}}$ and $\mathrm{SO}_{2}$ emissions. These increases were attributed to the increased nitrogen and sulfur content in the bio-oil when compared to the fossil fuels. Pyrolysis oil from switchgrass, miscanthus, and eucalyptus were blended with ethanol and tested as fuel in a commercial boiler (40 kWth) [121]. A 20-80\% blend of pyrolysis oil and ethanol resulted in a clean burn. Adjusting the boiler settings were necessary since the stoichiometric air: fuel ratios for ethanol and pyrolysis oil were lower than that for fuel oil. Utilizing low $\mathrm{N}$ feedstock to produce the pyrolysis oil was found to result in a reduction to the boiler $\mathrm{NO}_{\mathrm{x}}$ emissions when compared to the type \#2 fuel oil.

Pyrolysis gas has also been investigated as fuel in both compressions and spark ignition engines. Increased $\mathrm{NO}_{x}$ emissions under pyrolysis gas combustion were attributed to the high flame temperature which resulted from the increased $\mathrm{H}_{2}$ amount in the gas. Lean conditions were found to enable the reduction of $\mathrm{NO}_{\mathrm{x}}$ emissions and increased the engine thermal efficiency but resulted in a relative increase in $\mathrm{CO}$ emissions [122]. Shah et al. [123] found $\mathrm{CO}$ and $\mathrm{NO}_{\mathrm{x}}$ concentrations in the exhaust from syngas-powered generators to be lower than under gasoline operation. Adjustment to engine design, such as increased compression ratio, optimizing injection timing and stratified charging can improve engine performance and reduce emissions under gasification and pyrolysis-derived gases [124].

Animal manure as feedstock for pyrolysis conversion exists in a few studies compared to the majority of available literature focusing on poultry litter pyrolysis. Pyrolysis of poultry litter yielded bio-oil 15-30 wt. \% of the original feed, an HHV of 26-29 MJ. $\mathrm{kg}^{-1}$ and dynamic viscosity of $0.01-27.9 \mathrm{~Pa}$, respectively [125]. The temperature remained the most instrumental parameter impacting conversion in a multi-parameter study of pyrolysis of poultry litter-wood shaving mixture within a fluidized-bed 
reactor; the other factors were biomass feed rate and $\mathrm{N}_{2}$ flow rate respectively [126]. The highest bio-oil yield was 51 wt. \%, at $\mathrm{pH}, 4.85$ within temperatures of $475{ }^{\circ} \mathrm{C}$. Investigations were carried out for swine compost, wood chips, and sewage sludge as a potential feedstock for bio-oil production in a fluidized-bed pyrolysis unit [127]. The swine compost bio-oil yielded $\mathrm{H} / \mathrm{C}$ ratio of 1.63 , a higher heating value (HHV) of $31.2 \mathrm{MJ} \cdot \mathrm{kg}^{-1}$, in comparison to 1.68 and $27.0 \mathrm{MJ} \cdot \mathrm{kg}^{-1}$ for sewage sludge, and 1.51 and $23.9 \mathrm{MJ} \cdot \mathrm{kg}^{-1}$ for wood shavings. Implementation of pyrolysis conversion and thermochemical conversion are impeded by the high moisture and ash contents of animal waste. Mineral and alkali salts control the pyrolysis conversion pathways, and the resultant oxygenates which are available in varying quantities in manure, further adding uncertainty to the bio-oil products generated. Production of char could be an added advantage of animal wastes pyrolysis that recently came to attention. Char or "charcoal", is the solid residuals of the devolatilization of volatile organics and the partial reaction of biomass fixed carbon.

Researchers pyrolyzed untreated separated solid swine manure as well as solids which had undergone chemical or biological pretreatment before separation [25]. The chemically pre-treated and anaerobically digested swine manure solids had comparable properties and showed similar performance during thermogravimetric analysis. Nonetheless, the energy content of the gas resulted from the pyrolysis process contain about $30 \%$ of the original energy of the swine manure solids in the case of the anaerobically digested materials and about $60 \%$ of the chemically pre-treated swine manure solids. Swine separated-solids; paved-feedlot manure; dairy manure; poultry litter; and turkey litter were pyrolyzed. Manure-based biochar physicochemical and thermochemical characteristics were evaluated [128]. It was found that dairy biochars contained the most significant volatile matter, $\mathrm{C}$, and energy content and the lowest ash, N, and S contents. Swine biochars had the most significant $\mathrm{P}, \mathrm{N}$, and $\mathrm{S}$ contents alongside the lowest $\mathrm{pH}$ and $\mathrm{EC}$ values.

\subsection{Swine Manure Hydrothermal Liquefaction}

The liquefaction process is a promising technology for converting wastewater feedstock into bio-oil [129]. It has been utilized to convert a variety of wastewater feedstocks including swine manure, cattle manure, microalgae, macroalgae, and sludge [130,131]. During liquefaction, water serves as the reaction medium, lessening the need to dry the feedstock. As mentioned earlier, drying is a significant energy input for biofuel production. Liquefaction takes place under the temperature range of $200-350{ }^{\circ} \mathrm{C}$ and pressure of 5-15 MPa. Under these conditions feedstock macromolecules breakdown and reform biofuel [132]. Self-separation of the bio-oil from water is then enabled as the reaction solution returns to standard conditions. The produced bio-oil can be combusted or upgraded to be similar to petroleum oils [133]. Liquefaction bio-oil contains a wide range of chemical compounds such as straight and branched aliphatic compounds, aromatics and phenolic derivatives, carboxylic acids, esters, and nitrogenous ring structures [132,134]. Biller and Ross [130] reported that the class of compounds identified in the bio-oil is affected by the existence of protein and carbohydrate. The high oxygen/nitrogen content is the core factor differentiating bio-oils from petroleum oils [134] and results in detrimental biofuel qualities such as bio-oil acidity, polymerization, high viscosity, and high-boiling distribution. Furthermore, the varied chemical composition of bio-oil affects the combustion enactment, storage constancy, upgrading response, and economic value.

Liquefaction treatment system was developed to liquefy swine and dairy manures. The excess water content serves as the carrier fluid and reaction medium for direct liquefaction [96]. This process employs exceptional water properties that only occur in the vicinity of the critical region. The supercritical water denotes to the water at temperatures above its critical point, i.e., $374{ }^{\circ} \mathrm{C}$ and $22.1 \mathrm{MPa}$, with its density varying from 0.2 to $0.7 \mathrm{~g} \cdot \mathrm{cm}^{-3}$. As the supercritical water density decreases substantially from that of ordinary liquid water, hydrogen bonds between water molecules profoundly weaken resulting in shallow values of dielectric constant, comparable to those polar organic solvents. Liquefaction hydrolyzes the lignocellulosic components in the feedstock and converts it into lighter organic oils (bio-oils). The metal salts naturally present in the waste assist in catalyzing the hydrolysis reactions. When compared to 
pyrolysis, liquefaction takes place at lower temperatures and higher pressure. Researchers developed batch and continuous liquefaction experiments on swine manure with total solids of 20-27 wt. \% [135]. They reported that in the batch system under reactor temperatures ranging between 285 and $350{ }^{\circ} \mathrm{C}$ and CO atmosphere, the oil yield reached $76.2 \%$ of the volatile solid. The swine bio-oil had a higher heating value of $36.4 \mathrm{MJ} \cdot \mathrm{kg}^{-1}$. They also mentioned that additional processing of the oils is needed due to the existence of nitrogen and sulfur. Continuous operation under the reactor temperature of $305^{\circ} \mathrm{C}$ and pressure of $10.3 \mathrm{MPa}$, resulted in slight decreases for both the maximum oil production to $70.4 \%$ and the bio-oil's heating value, to $31.1 \mathrm{MJ} \cdot \mathrm{kg}^{-1}$ (a $23.4 \%$ decrease). As a waste treatment alternative, liquefaction reduced the initial swine waste stream's COD by $64.5 \%$. The authors concluded that further treatment of the wastewater is necessary before discharging because no reductions in the N, P, and K of the post-treated stream were observed. Supercritical liquefaction processing was used to convert swine manure into a liquid fuel [136]. Swine manure ethanol was used as a solvent in an autoclave in the temperature range of $240-360{ }^{\circ} \mathrm{C}$. The oil yield was evaluated by Fourier Transform Infrared spectroscopy (FTIR), elemental analyses, heating values, water content analyses, ash content and solids content. The results showed that the yield of the liquefaction products was significantly influenced by the reaction temperature. The maximum oil yield of $26.7 \%$ (of dry matter) with low oxygen content $(11.48 \%$ ) and heating value of $33.98 \mathrm{MJ} \cdot \mathrm{kg}^{-1}$ were achieved at a reaction temperature of $300^{\circ} \mathrm{C}$.

\subsection{Swine Manure Carbonization}

Biochar is the main solid byproduct of the carbonization process. The characteristics of this char are a function of the composition of the first biomass and the conversion severity. On the other hand, ash (mineral oxides with no carbon) is produced from complete combustion. Contrastingly, carbonization, pyrolysis, and gasification produce a carbon-rich solid constituent (char) that also contains the ash minerals. In a process less severe than pyrolysis or gasification, char can be produced in a dedicated procedure at temperatures between $250{ }^{\circ} \mathrm{C}$ and $400{ }^{\circ} \mathrm{C}$ in the absence of air or oxygen. This process is referred to as slow-pyrolysis, carbonization or torrefaction. Torrefaction is a mild thermal treatment taking place at lower temperatures $\left(200-300{ }^{\circ} \mathrm{C}\right)$ in which the biomass matrix remains unmodified mainly except for the easily devolatilized fraction (hemicellulose). The process improves friability and energy density of the biomass, facilitating co-firing with coal, or stand-alone conversion [137]. Char is utilized for soil quality improvement, including filtration and adsorption media [138], incineration as a blend-in with fossil coal or as a stand-alone solid fuel. Biochar is used to indicate the specific end-use of the produced char as a soil amendment [139]. Compared with other sophisticated thermochemical conversion technologies, such as fluidized bed gasification and fast pyrolysis, carbonization (or slow pyrolysis) necessitates relatively low technical resources, making the process suitable for farm-scale [140]. The biochar produced from animal wastes can easily be transported and stored without irritation odor and deterioration. It can be eagerly used as a cooking fuel and feedstock for existing coal power plants. Bio-char is higher in quality to charcoal produced from coal due to its low sulfur content and high reactivity.

Numerous advantages of incorporation of biochar in the soil have been learned through studying these soils. Biochar contains aromatic carbon structures that provide a stable carbon form facilitating nutrients retention. Furthermore, porous biochar structures ameliorate the soil qualities facilitating the growth of microbial microorganisms. Soil cation exchange capacity (CEC) is also improved due to the increased alkalinity of the soil. A study was carried out on impacts of biochar origins (cotton trash, grass clippings, and prunings) verses biochar application rates $\left(10,50\right.$ and $100 \mathrm{t} \cdot \mathrm{ha}^{-1}$ ) on a radish crop in Alfisol soil [141]. Even with the highest rate of biochar application, nitrogen fertilization was shown to be necessary despite the fact that $\mathrm{C} / \mathrm{N}$ for biochar is quite high about 200. Radish dry matter production improved with increasing biochar application rates as well as the interaction between $\mathrm{N}$ fertilization and biochar. Additionally, there were general improvements in soil quality; soil $\mathrm{pH}$, exchangeable alkali ions ( $\mathrm{Na}, \mathrm{K}$ and $\mathrm{Ca}$ ) and a decrease in the soil tensile strength, with the incorporation of biochar. Recent studies revealed that incorporation of biochar in the soil 
not only improves soil properties and immobilizes heavy metals, it also mitigate carbon emissions by sequestering carbon in a stable form.

With temperature increase, from 100 to $700{ }^{\circ} \mathrm{C}$, biomass underwent progressive structural transformation classified into four stages: transition char, amorphous char, composite char, and lastly, turbostratic char [142]. There was an inverse correlation between the biochar degradation in the soil and pyrolysis temperatures [143]. Under low-severity conversion, residual cellulose and hemicellulose in the biochar matrix are quickly degraded and lost in the soil compared to aromatic biochar produced under increased temperatures $\left(525-575^{\circ} \mathrm{C}\right)$. However, higher pyrolysis/biochar production temperatures reduce the recoverable biochar mass. During corn stover pyrolysis, the influence of air injection on the quality of biochar as a soil amendment was investigated [144]. Higher organic carbon content was exhibited for chars produced at $0 \%$ and $10 \%$ air injection until week 6 of the study where differences became insignificant. There was more biologically available carbon in the $0 \%$ and $10 \%$ chars utilized during the first few weeks by the soil microorganisms. On the other hand, extractable $\mathrm{P}$ started to increase in week four due to increased microbial activity that facilitated char decomposition and $\mathrm{P}$ demineralization.

The great macro- and micro-nutrients content of manure solids has created interest in using them as biochar feedstock. Characteristics of biochar produced at $380{ }^{\circ} \mathrm{C}$ from different biomass feedstocks were studied [145]. Highest electrical conductivity, $2.90 \mathrm{mS} \cdot \mathrm{cm}^{-1}$, water retention capacity, $294 \%$, organic $\mathrm{N}, 0.25 \mathrm{mg} \cdot \mathrm{kg}^{-1}$, and phosphate, $0.76 \mathrm{mg} \cdot \mathrm{kg}^{-1}$ was exhibited by cattle sludge biochar. Soil incorporated swine manure and woodchip biochars were monitored for carbon emissions [146]. Soils treated with biochar maintained organic $\mathrm{C}$ with $\mathrm{CO}_{2}$ emissions equal to those from control soil. When compared with biochar-free soils, biochar application facilitated a reduction in carbon emissions with the application of manure digestate. Soils amended with both manure digestate and manure biochar reported the largest drop in Olsen P levels, but they still maintained more than $50 \mathrm{mg} \cdot \mathrm{kg}^{-1}$. Temperature effect on the quality of swine manure solids biochar was studied [147]. Increasing the charring temperature from 350 to $700{ }^{\circ} \mathrm{C}$ resulted in a drop in char yields from 62.3 to $36.4 \%$ of the original mass. A corresponding increase in aromatic and carbonyl carbon from the loss of alcoholic, paraffinic, and carboxylate carbon in the char carbon was reported. Physical characteristics of swine manure solids biochar generated at different temperatures, $400-800{ }^{\circ} \mathrm{C}$, through slow pyrolysis conditions (no air) were investigated [148]. The biochar yields varied from $39 \mathrm{wt}$. \% at $400{ }^{\circ} \mathrm{C}$ to $34 \mathrm{wt} . \%$ at $800{ }^{\circ} \mathrm{C}$. Increasing the pyrolysis temperature from 400 to $800{ }^{\circ} \mathrm{C}$, increased the $\mathrm{pH}$ of biochar solution ( $5 \mathrm{~g}$ biochar in $10 \mathrm{~mL}$ deionized water) from 7.5 to 11.4. Furthermore, it increased biochar P content, porosity, and surface area to $7.7 \mathrm{wt} . \%, 0.13$, and $63 \mathrm{~m}^{2} \cdot \mathrm{g}^{-1}$, respectively. A series of biochars were produced from dried swine manure waste via slow pyrolysis at different temperatures, i.e., $400-800^{\circ} \mathrm{C}$ [149]. The produced biochar was examined for its prospective use as a soil amendment. It was observed that increasing the reactor temperature improved the pore characteristics, ash contents and $\mathrm{pH}$ values of all swine-manure-derived biochars, whereas it decreased the yield and N/O contents.

Most biochar literature reported adoption of torrefaction, slow pyrolysis (carbonization), or flash pyrolysis as the conversion technologies [149]. Although pyrolysis-derived biochar contains more char carbon in principle, only a fraction of this carbon is raw unconverted cellulosic carbon readily degraded by microorganisms upon soil application as revealed by studies. Consequently, a rapid carbon loss from the biochar reduces its sequestration potential. Bio-oil studies point out some challenges facing pyrolysis including; storage, transportation, pretreatment and upgrading, the energetics and economics of biochar production via pyrolysis would, therefore, be further constrained.

\subsection{Challenges Associated with Swine Manure Thermochemical Conversion}

In addition to the manure thermochemical conversion challenges mentioned earlier, some other issues might hinder the advancements of these conversion technologies. This section will cover issues associated with generic biomass types due to the nonexistence of full-scale research on thermochemical conversion of swine manure. The following items are a collection of previously cited issues which are 
listed here to highlight the reasons for failures. Accordingly, they might initiate research strategies to overcome these issues. It should be revealed that this list is not so conclusive. The failures of biomass thermochemical conversion systems have resulted from design problems, i.e., poorly designed conveyor systems, wrong selection of vessels walls thickness, mistakes in selecting the steam and expansion joints. Additionally, operational and maintenance problems, i.e., lack of maintenance of material handling systems, insufficient control and monitoring, poor bio-oil conversion to gasoline, and cracks in concrete chambers due to heat and corrosion. Moreover, downstream issues, i.e., excess of the limits of dioxins emission, ignition of produced hot char, pipe burst, and low energy recovery.

\section{Conclusions}

- Increases in scale and aggregation of swine production farms have resulted in manure accumulation problems in high production regions.

- Various manure management technologies, i.e., biological, and thermochemical, could be utilized to convert swine manure to value-added products while mitigating its negative impacts on surrounding ecosystems.

- Thermochemical conversion technologies are mature, stable and modular but, so far, underutilized in swine manure management.

- Gasification of swine manure solids, although under-investigated, can overcome the challenges associated with high-ash feedstock, and also generate a biochar stream.

- There is a need for integrating the swine manure biological and thermochemical conversion technologies to maximize the benefit of such a feedstock.

- There is a lack of research studies that investigate the kinetics of swine manure solids decomposition. These solids could be produced from biological conversion or solid separation technologies.

- It is crucial to develop comprehensive assessments of environmental impacts of thermochemical conversion as a manure management strategy.

Acknowledgments: Acknowledgment is due to the Agriculture and Food Research Initiative for their support of the Competitive Grant No. 2011-68002-30208 from the USDA National Institute of Food and Agriculture. Their financial support is much appreciated.

Conflicts of Interest: The authors declare no conflict of interest.

\section{References}

1. USDA-NASS. Quarterly Hogs and Pigs December 2017. ISSN 1949-1921. Available online: http:/ / usda. mannlib.cornell.edu/usda/current/HogsPigs/HogsPigs-12-22-2017.pdf (accessed on 26 February 2018).

2. American Society of Agricultural and Biological Engineers (ASABE). Standard D3843.2. In Manure Production and Characteristics 2005; ASABE: St. Joseph, MI, USA, 2005.

3. Tilman, D.; Cassman, K.G.; Matson, P.A.; Naylor, R.; Polasky, S. Agricultural sustainability and intensive production practices. Nature 2002, 418, 671-677. [CrossRef] [PubMed]

4. USDA-NASS. Overview of the U.S. Hog Industry; NASS: Washington, DC, USA, 2009.

5. Fantozzi, F.; Bartocci, P.; D’Alessandro, B.; Arampatzis, S.; Manos, B. Public-private partnerships value in bioenergy projects: Economic feasibility analysis based on two case studies. Biomass Bioenergy 2014, 66, 387-397. [CrossRef]

6. Manos, B.; Partalidou, M.; Fantozzi, F.; Arampatzis, S.; Papadopoulou, O. Agro-energy districts contributing to environmental and social sustainability in rural areas: Evaluation of a local public-private partnership scheme in Greece. Renew. Sustain. Energy Rev. 2014, 29, 85-95. [CrossRef]

7. Manos, B.; Bartocci, P.; Partalidou, M.; Fantozzi, F.; Arampatzis, S. Review of public-private partnerships in agro-energy districts in Southern Europe: The cases of Greece and Italy. Renew. Sustain. Energy Rev. 2014, 39, 667-678. [CrossRef]

8. Hodgkinson, R.A.; Chambers, B.J.; Withers, P.J.A.; Cross, R. Phosphorus losses to surface waters following organic manure applications to a drained clay soil. Agric. Water Manag. 2002, 57, 155-173. [CrossRef] 
9. Novak, J.M.; Watts, D.W.; Hunt, P.G.; Stone, K.C. Phosphorus movement through a coastal plain soil after a decade of intensive swine manure application. J. Environ. Qual. 2000, 29, 1310-1315. [CrossRef]

10. Aguirre-Villegas, H.A.; Larson, R.; Reinemann, D.J. From waste-to-worth: Energy, emissions, and nutrient implications of manure processing pathways. Biofuels Bioprod. Biorefin. 2014, 8, 770-793. [CrossRef]

11. Miller, J.J.; Chanasyk, D.S.; Curtis, T.W.; Olson, B.M. Phosphorus and nitrogen in runoff after phosphorus- or nitrogen-based manure applications. J. Environ. Qual. 2011, 40, 949-958. [CrossRef] [PubMed]

12. Salvano, E.; Flaten, D.N.; Rousseau, A.N.; Quilbe, R. Are current phosphorus risk indicators useful to predict the quality of surface waters in southern Manitoba, Canada? J. Environ. Qual. 2009, 38, 2096-2105. [CrossRef] [PubMed]

13. OSU. Ohio Livestock Manure and Wastewater Management Guide; Bulletin 604; Ohio State University Extension: Columbus, OH, USA, 2000; Available online: https://agcrops.osu.edu/sites/agcrops / files/imce/fertility / bulletin_604.pdf (accessed on 10 January 2018).

14. Prince Edward Island. Guidelines for Manure Management for Prince Edward Island; Government of Prince Edward Island: Charlottetown, PE, Canada, 2000. Available online: http:/ / www.gov.pe.ca/agric/index. php3?number=70588\&lang=F (accessed on 20 December 2017).

15. Day, D.; Funk, T.; Hatfield, J.; Stewart, B. Processing Manure: Physical, Chemical and Biological Treatment, in Animal Waste Utilization: Effective Use of Manure as a Soil Resource; CRC Press: Boca Raton, FL, USA, 1998.

16. Sadaka, S.; Van Devender, K. Evaluation of Chemically Coagulated Swine Manure Solids as Value-Added Products. J. Sustain. Bioenergy Syst. 2015, 5, 136-150. [CrossRef]

17. Zhang, R.H.; Westerman, P.W. Solid-liquid separation of animal manure for odor control and nutrient management. Appl. Eng. Agric. 1997, 13, 657-664. [CrossRef]

18. Hjorth, M.; Christensen, K.V.; Christensen, M.L.; Sommer, S.G. Solid-liquid separation of animal slurry in theory and practice-A review. Agron. Sustain. Dev. 2009, 30, 153-180. [CrossRef]

19. Ford, M.; Fleming, R. Mechanical Solid-Liquid Separation of Livestock Manure—Literature Review; Prepared for Ontario Pork; Ridgetown College, University of Guelph: Ridgetown, ON, Canada, 2002; Available online: http:/ / mie.esab.upc.es/ms/informacio/residus_ramaders/Separator\%20manure.pdf (accessed on 17 March 2015).

20. Rodriguez, M.D.E.; del Puerto, A.M.G.; Montealegre, M.L.M.; Adamsen, A.P.S.; Gullov, P.; Sommer, S.G. Separation of phosphorus from pig slurry using chemical additives. Appl. Eng. Agric. 2005, 21, 739-742. [CrossRef]

21. Xiu, S.; Zhang, Y.; Shahbazi, A. Swine manure solids separation and thermochemical conversion to heavy oil. BioResources 2009, 4, 458-470.

22. Hjorth, M.; Christensen, M.L.; Christensen, P.V. Flocculation, coagulation, and coagulation of manure affecting three separation techniques. Bioresour. Technol. 2008, 99, 8598-8604. [CrossRef] [PubMed]

23. Powers, W.J.; Flatow, L.A. Flocculation of swine manure: Influence of flocculant, rate of addition, and diet. Appl. Eng. Agric. 2002, 18, 609-614. [CrossRef]

24. Christensen, M.L.; Hjorth, M.; Keidling, K. Characterization of pig slurry with reference to flocculation and separation. Water Res. 2009, 43, 773-783. [CrossRef] [PubMed]

25. Wnetrzak, R.; Kwapinski, W.; Peters, K.; Sommer, S.G.; Jensen, L.S.; Leahy, J.J. The influence of the pig manure separation system on the energy production potentials. Bioresour. Technol. 2013, 136, 502-508. [CrossRef] [PubMed]

26. Mohammed, M.; Egyir, I.S.; Donkor, A.K.; Amoah, P.; Nyarko, S.; Boateng, K.K.; Ziwu, C. Feasibility study for biogas integration into waste treatment plants in Ghana. Egypt. J. Pet. 2017, 26, 695-703. [CrossRef]

27. Labatut, R.A.; Angenent, L.T.; Scott, N.R. Conventional Mesophilic vs. Thermophilic anaerobic digestion: A trade-off between performance and stability? Water Res. 2014, 53, 249-258. [CrossRef] [PubMed]

28. Sweeten, J.M.; Korenberg, J.; LePori, W.A.; Annamalai, K.; Parnell, C.B. Combustion of cattle feedlot manure for energy production. Energy Agric. 1986, 5, 55-72. [CrossRef]

29. Bernal, M.P.; Sánchez-Monedero, M.A.; Paredes, C.; Roig, A. Carbon mineralization from organic wastes at different composting stages during their incubation with soil. Agric. Ecosyst. Environ. 1998, 69, 175-189. [CrossRef]

30. Finestein, M.S.; Miller, F.C.; Strom, P.F. Monitoring and evaluating composting process performance. J. WPCF 1986, 58, 272-278. 
31. Tiquia, S.; Richard, T.; Honeyman, M. Effect of windrow turning and seasonal temperatures on composting of hog manure from hoop structures. Environ. Technol. 2000, 21, 1037-1046. [CrossRef]

32. Sadaka, S.S.; Richard, T.L.; Loecke, T.D.; Liebman, M. Determination of Compost Respiration Rates Using Pressure Sensors. Compos. Sci. Util. 2006, 14, 124-131. [CrossRef]

33. Gamroth, M.J. Composting: An Alternative for Livestock Manure Management and Disposal of Dead Animals; The Ohio State University: Columbus, OH, USA, 2012.

34. Gajalakshmi, S.; Abbasi, S.A. Solid Waste Management by Composting: State of the Art. Crit. Rev. Environ. Sci. Technol. 2008, 38, 311-400. [CrossRef]

35. Lau, A.K.; Lo, K.V.; Liao, P.H.; Yu, J.C. Aeration experiments for swine waste composting. Bioresour. Technol. 1992, 41, 145-152. [CrossRef]

36. Huang, G.; Wu, Q.; Wong, J.; Nagar, B. Transformation of organic matter during co-composting of pig manure with sawdust. Bioresour. Technol. 2006, 97, 1834-1842. [CrossRef] [PubMed]

37. Bernal, M.; Alburquerque, J.; Moral, R. Composting of animal manures and chemical criteria for compost maturity assessment. A review. Bioresour. Technol. 2009, 100, 5444-5453. [CrossRef] [PubMed]

38. Ahn, H.K.; Mulbry, W.; White, J.; Kondrad, S. Pile mixing increases greenhouse gas emissions during composting of dairy manure. Bioresour. Technol. 2011, 102, 2904-2909. [CrossRef] [PubMed]

39. U.S. EPA. Operating Anaerobic Digester Projects December 2014; U.S. EPA: Washington, DC, USA, 2014.

40. EPA. Inventory of U.S. Greenhouse Gas Emissions and Sinks: 1990-2011; EPA 430-R-13-001; EPA: Washington, DC, USA, 2013.

41. Wang, Q.; Kuninobu, M.; Ogawa, H.I.; Kato, Y. Degradation of volatile fatty acids in highly efficient anaerobic digestion. Biomass Bioenergy 1999, 16, 407-416. [CrossRef]

42. Ahring, B.K.; Sandberg, M.; Angelidaki, I. Volatile fatty acids as indicators of process imbalance in anaerobic digestors. Appl. Microbiol. Biotechnol. 1995, 43, 559-565. [CrossRef]

43. Chen, H.; Li, B.; Yang, H.; Yang, G.; Zhang, S. Experimental investigation of biomass gasification in a fluidized bed reactor. Energy Fuels 2008, 22, 3493-3498.

44. Angelidaki, I.; Ahring, B. Thermophilic anaerobic digestion of livestock waste: The effect of ammonia. Appl. Microbiol. Biotechnol. 1993, 38, 560-564. [CrossRef]

45. Hansen, K.H.; Angelidaki, I.; Ahring, B.K. Anaerobic digestion of swine manure: Inhibition by ammonia. Water Res. 1998, 32, 5-12. [CrossRef]

46. Wu, X.; Yao, W.; Zhu, J.; Miller, $\mathrm{C}$. Biogas and $\mathrm{CH}_{4}$ productivity by co-digesting swine manure with three crop residues as an external carbon source. Bioresour. Technol. 2010, 101, 4042-4047. [CrossRef] [PubMed]

47. Lyberatos, G.; Skiadas, I. Modelling of anaerobic digestion-A review. Glob. Nest Int. J. 1999, 1, 63-76.

48. Gallert, C.; Winter, J. Mesophilic and thermophilic anaerobic digestion of source-sorted organic wastes: Effect of ammonia on glucose degradation and methane production. Appl. Microbiol. Biotechnol. 1997, 48, 405-410. [CrossRef]

49. Vindis, P.; Mursec, B.; Janzekovic, M.; Cus, F. The impact of mesophilic and thermophilic anaerobic digestion on biogas production. J. Achiev. Mater. Manuf. Eng. 2009, 36, 192-198.

50. Chen, Y.; Cheng, J.J.; Creamer, K.S. Inhibition of anaerobic digestion process: A review. Bioresour. Technol. 2008, 99, 4044-4064. [CrossRef] [PubMed]

51. Rajagopal, R.; Massé, D.I.; Singh, G. A critical review on inhibition of anaerobic digestion process by excess ammonia. Bioresour. Technol. 2013, 143, 632-641. [CrossRef] [PubMed]

52. Mukhtar, S.; Goodrich, B. Dairy Biomass as a Renewable Fuel Source; Texas Agri-Life Extension Service Publication No. L-5494; Texas A\&M University: College Station, TX, USA, 2008.

53. Jenkins, B.; Baxter, L.; Miles, T., Jr.; Miles, T. Combustion properties of biomass. Fuel Process. Technol. 1998, 54, 17-46. [CrossRef]

54. Energie Centrum Nederland (ECN). Phyllis, the Composition of Biomass and Waste; ECN: Sint Maartensvlotbrug, The Netherlands, 2007; Available online: www.ecn.nl/phyllis2 (accessed on 12 October 2014).

55. Adani, F.; Baido, D.; Calcaterra, E.; Genevini, P. The influence of biomass temperature on biostabilization-Biodrying of municipal solid waste. Bioresour. Technol. 2002, 83, 173-179. [CrossRef]

56. Suler, D.J.; Finstein, M.S. Effect of temperature, aeration, and moisture on $\mathrm{CO}_{2}$ formation in bench-scale, continuously Thermophilic composting of solid waste. Appl. Environ. Microbiol. 1977, 33, 345-350. [PubMed]

57. Sadaka, S.; Ahn, H. Evaluation of a biodrying process for beef, swine, and poultry manures mixed separately with corn stover. Appl. Eng. Agric. 2012, 28, 457-463. [CrossRef] 
58. Li, X.; Zhang, R.; Pang, Y. Characteristics of dairy manure composting with rice straw. Bioresour. Technol. 2008, 99, 359-367. [CrossRef] [PubMed]

59. Hong, J.H.; Matsuda, J.; Ikeuchi, Y. High rapid composting of dairy cattle manure with crop and forest residues. Trans. ASAE 1983, 26, 533-541. [CrossRef]

60. Gao, M.; Li, B.; Yu, A.; Liang, F.; Yang, L.; Sun, Y. The effect of aeration rate on forced-aeration composting of chicken manure and sawdust. Bioresour. Technol. 2010, 101, 1899-1903. [CrossRef] [PubMed]

61. Sharara, M.A.; Sadaka, S.; Costello, T.A.; VanDevender, K. Influence of aeration rate on the physio-chemical characteristics of biodried dairy manure-wheat straw mixture. Appl. Eng. Agric. 2012, 28, 407-415. [CrossRef]

62. Mason, D.M.; Gandhi, K.N. Formulas for calculating the calorific value of coal and coal chars: Development, tests, and uses. Fuel Process. Technol. 1983, 7, 11-22. [CrossRef]

63. Cordero, T.; Marquez, F.; Rodriguez-Mirasol, J.; Rodriguez, J. Predicting heating values of lignocellulosics and carbonaceous materials from proximate analysis. Fuel 2001, 80, 1567-1571. [CrossRef]

64. Channiwala, S.A.; Parikh, P.P. A unified correlation for estimating HHV of solid, liquid and gaseous fuels. Fuel 2002, 81, 1051-1063. [CrossRef]

65. Zhang, Y.; Li, B.; Li, H.; Liu, H. Thermodynamic evaluation of biomass gasification with air in autothermal gasifiers. Thermochim. Acta 2011, 519, 65-71. [CrossRef]

66. Thygesen, A.; Wernberg, O.; Skou, E.; Sommer, S.G. Effect of incineration temperature on phosphorus availability in bio-ash from manure. Environ. Technol. 2011, 32, 633-638. [CrossRef] [PubMed]

67. Park, M.H.; Kumar, S.; Ra, C. Solid Waste from Swine Wastewater as a Fuel Source for Heat Production. Asian-Aust. J. Anim. Sci. 2012, 25, 1627-1633. [CrossRef] [PubMed]

68. Otero, M.; Sánchez, M.E.; Gómez, X. Co-firing of coal and manure biomass: A TG-MS approach. Bioresour. Technol. 2011, 102, 8304-8309. [CrossRef] [PubMed]

69. Fernandez-Lopez, M.; Puig-Gamero, M.; Lopez-Gonzalez, D.; Avalos-Ramirez, A.; Valverde, J.; Sanchez-Silva, L. Life cycle assessment of swine and dairy manure: Pyrolysis and combustion processes. Bioresour. Technol. 2015, 182, 184-192. [CrossRef] [PubMed]

70. Xiu, S.; Rojanala, H.K.; Shahbazi, A.; Fini, E.H.; Wang, L. Pyrolysis and combustion characteristics of Bio-oil from swine manure. J. Therm. Anal. Calorim. 2011, 107, 823-829. [CrossRef]

71. Komiyama, T.; Kobayashi, A.; Yahagi, M. The chemical characteristics of ashes from cattle, swine and poultry manure. J. Mater. Cycles Waste Manag. 2013, 15, 106-110. [CrossRef]

72. Petrus, L.; Noordermeer, M.A. Biomass to biofuels, a chemical perspective. Green Chem. 2006, 8, 861-867. [CrossRef]

73. Yung, M.M.; Jablonski, W.S.; Magrini-Bair, K.A. Review of catalytic conditioning of biomass-derived syngas. Energy Fuels 2009, 23, 1874-1887. [CrossRef]

74. Sadaka, S.S.; Ghaly, A.E.; Sabbah, M.A. Two-phase biomass air-steam gasification model for fluidized bed reactors: Part III-Model validation. Biomass Bioenergy 2002, 22, 479-487. [CrossRef]

75. Lv, P.; Xiong, Z.; Chang, J.; Wu, C.; Chen, Y.; Zhu, J. An experimental study on biomass air-steam gasification in a fluidized bed. Bioresour Technol. 2004, 95, 95-101. [CrossRef] [PubMed]

76. Kumar, A.; Wang, L.; Dzenis, Y.A.; Jones, D.D.; Hanna, M.A. Thermogravimetric characterization of corn stover as gasification and pyrolysis feedstock. Biomass Bioenergy 2008, 32, 460-467. [CrossRef]

77. González, J.; Román, S.; Bragado, D.; Calderón, M. Investigation on the reactions influencing biomass air and air/steam gasification for hydrogen production. Fuel Process. Technol. 2008, 89, 764-772. [CrossRef]

78. Prins, M.J.; Ptasinski, K.J.; Janssen, F.J.J.G. Thermodynamics of gas-char reactions: First and second law analysis. Chem. Eng. Sci. 2003, 58, 1003-1011. [CrossRef]

79. Reed, T.; Reed, T.B.; Das, A.; Das, A. Handbook of Biomass Downdraft Gasifier Engine Systems: Biomass Energy Foundation; National Technical Information Service, U.S. Department of Commerce: Alexandria, VA, USA, 1988.

80. Balat, M.; Balat, M.; Kırtay, E.; Balat, H. Main routes for the thermo-conversion of biomass into fuels and chemicals. Part 2: Gasification systems. Energy Convers. Manag. 2009, 50, 3158-3168. [CrossRef]

81. Di Blasi, C.; Signorelli, G.; Portoricco, G. Countercurrent fixed-bed gasification of biomass at laboratory scale. Ind. Eng. Chem. Res. 1999, 38, 2571-2581. [CrossRef]

82. Van der Walt, I.J.; Nel, J.T.; Glasser, D.; Hildebrandt, D.; Ngubevana, L. An Economic Evaluation for Small Scale Thermal Plasma Waste-to-Energy Systems. 2012, pp. 1-4. Available online: https:/ /www.yumpu.com/ en/document/view / 24349230/an-economic-evaluation-for-small-scale-plasma-waste-to-energy (accessed on 14 February 2018). 
83. Rajasekhar, M.; Rao, N.V.; Rao, G.C.; Priyadarshini, G.; Kumar, N.J. Energy generation from municipal solid waste by innoviative technologies-Plasma gasification. Procedia Mater. Sci. 2015, 10, 513-518. [CrossRef]

84. Bosmans, A.; Wasan, S.; Helsen, L. Waste to clean syngas: Avoiding tar problems. In Proceedings of the 2nd International Academic Symposium on Enhanced Landfill Mining, Houthalen-Helchteren, Belgium, 15-16 October 2013.

85. Campos, U.; Zamenian, H.; Koo, D.D.; Goodman, D.W. Waste-to-energy technology applications for municipal solid waste (MSW) treatment in the urban environment. Int. J. Emerg. Technol. Adv. Eng. 2015, 5, 504-508.

86. Gray, L. Plasma gasification as a viable waste-to-energy treatment of municipal solid waste. In MANE 6960-Solid and Hazardous Waste Prevention and Control Engineering; Rensselaer Hartford: Hartford, CT, USA, 2014; pp. 1-15.

87. Heberlein, J.; Murphy, A.B. Thermal plasma waste treatment. J. Phys. D Appl. Phys. 2008, 41, 1-20. [CrossRef]

88. Sirillova, I.L. Waste treatment by plasma technology. Transf. Inovacii 2015, 31, 40-42.

89. Cairns, E.; Tevebaugh, A. CHO Gas Phase Compositions in Equilibrium with Carbon, and Carbon Deposition Boundaries at One Atmosphere. J. Chem. Eng. Data 1964, 9, 453-462. [CrossRef]

90. Narvaez, I.; Orio, A.; Aznar, M.P.; Corella, J. Biomass gasification with air in an atmospheric bubbling fluidized bed. Effect of six operational variables on the quality of the produced raw gas. Ind. Eng. Chem. Res. 1996, 35, 2110-2120.

91. Gai, C.; Dong, Y. Experimental study on non-woody biomass gasification in a downdraft gasifier. Int. J. Hydrog. Energy 2012, 37, 4935-4944. [CrossRef]

92. Baker, E.; Brown, M.; Elliott, D.; Mudge, L. Characterization and treatment of tars and biomass gasifiers. In Proceedings of the American Institute of Chemical Engineers Summer National Meeting, Denver, CO, USA, 21-24 August 1988.

93. Boerrigter, H.; den Uil, H.; Calis, H. Green diesel from biomass via Fischer-Tropsch synthesis: New insights in gas cleaning and process design. In Proceedings of the Pyrolysis and Gasification of Biomass and Waste Expert Meeting, Strasbourg, France, 30 September-1 October 2002; pp. 371-383.

94. Tijmensen, M.J.; Faaij, A.P.; Hamelinck, C.N.; van Hardeveld, M.R. Exploration of the possibilities for production of Fischer Tropsch liquids and power via biomass gasification. Biomass Bioenergy 2002, 23, 129-152. [CrossRef]

95. Higman, C.; Van der Burgt, M. Gasification; Gulf Professional Publishing: Houston, TX, USA, 2003.

96. Cantrell, K.; Ro, K.; Mahajan, D.; Anjom, M.; Hunt, P.G. Role of thermochemical conversion in livestock waste-to-energy treatments: Obstacles and opportunities. Ind. Eng. Chem. Res. 2007, 46, 8918-8927. [CrossRef]

97. Zhang, S.; Cao, J.; Takarada, T. Effect of pretreatment with different washing methods on the reactivity of manure char. Bioresour. Technol. 2010, 101, 6130-6135. [CrossRef] [PubMed]

98. Arvelakis, S.; Gehrmann, H.; Beckmann, M.; Koukios, E.G. Preliminary results on the ash behavior of peach stones during fluidized bed gasification: Evaluation of fractionation and leaching as pre-treatments. Biomass Bioenergy 2005, 28, 331-338. [CrossRef]

99. Roy, P.C.; Datta, A.; Chakraborty, N. Assessment of cow dung as a supplementary fuel in a downdraft biomass gasifier. Renew. Energy 2010, 35, 379-386. [CrossRef]

100. Gautam, G.; Adhikari, S.; Brodbeck, C.; Bhavnani, S.; Fasina, O.; Taylor, S. Gasification of wood chips, agricultural residues, and waste in a commercial downdraft gasifier. Trans. ASABE 2011, 54, 1801-1807. [CrossRef]

101. Morf, P.; Hasler, P.; Nussbaumer, T. Mechanisms and kinetics of homogeneous secondary reactions of tar from continuous pyrolysis of wood chips. Fuel 2002, 81, 843-853. [CrossRef]

102. Evans, R.J.; Milne, T.A. Molecular characterization of the pyrolysis of biomass. Energy Fuels 1987, 1, $123-137$. [CrossRef]

103. Vreugdenhil, B.; Zwart, R.; Neeft, J.P.A. Tar Formation in Pyrolysis and Gasification; ECN: Sint Maartensvlotbrug, The Netherlands, 2009.

104. Kuligowski, K.; Poulsen, T.G.; Rubæk, G.H.; Sørensen, P. Plant-availability to barley of phosphorus in ash from thermally treated animal manure in comparison to other manure based materials and commercial fertilizer. Eur. J. Agron. 2010, 33, 293-303. [CrossRef]

105. Bridgwater, A.; Meier, D.; Radlein, D. An overview of fast pyrolysis of biomass. Org. Geochem. 1999, 30, 1479-1493. [CrossRef] 
106. Meier, D.; Faix, O. State of the art of applied fast pyrolysis of lignocellulosic materials-A review. Bioresour. Technol. 1999, 68, 71-77. [CrossRef]

107. He, B.J.; Zhang, Y.; Yin, Y.; Funk, T.L.; Riskowski, G. Preliminary characterization of raw oil products from the thermochemical conversion of swine manure. Trans. ASAE 2001, 44, 1865-1871.

108. Mohan, D.; Pittman, C.U.; Steele, P.H. Pyrolysis of wood/biomass for bio-oil: A critical review. Energy Fuels 2006, 20, 848-889. [CrossRef]

109. Mullen, C.A.; Boateng, A.A. Chemical Composition of Bio-oils Produced by Fast Pyrolysis of Two Energy Crops. Energy Fuels 2008, 22, 2104-2109. [CrossRef]

110. Maggi, R.; Delmon, B. Comparison between 'slow'and 'flash' pyrolysis oils from biomass. Fuel 1994, 73, 671-677. [CrossRef]

111. Demirbaş, A. Mechanisms of liquefaction and pyrolysis reactions of biomass. Energy Convers. Manag. 2000, 41, 633-646. [CrossRef]

112. Diebold, J.P. A Review of the Chemical and Physical Mechanisms of the Storage Stability of Fast Pyrolysis Bio-Oils; National Renewable Energy Laboratory Golden: Golden, CO, USA, 2000.

113. Elliott, D.C. Historical developments in hydroprocessing bio-oils. Energy Fuels 2007, 21, 1792-1815. [CrossRef]

114. Huber, G.W.; Iborra, S.; Corma, A. Synthesis of transportation fuels from biomass: Chemistry, catalysts, and engineering. Chem. Rev. 2006, 106, 4044-4098. [CrossRef] [PubMed]

115. Rioche, C.; Kulkarni, S.; Meunier, F.C.; Breen, J.P.; Burch, R. Steam reforming of model compounds and fast pyrolysis bio-oil on supported noble metal catalysts. Appl. Catal. B Environ. 2005, 61, 130-139. [CrossRef]

116. Vagia, E.C.; Lemonidou, A.A. Thermodynamic analysis of hydrogen production via steam reforming of selected components of aqueous bio-oil fraction. Int. J. Hydrog. Energy 2007, 32, 212-223. [CrossRef]

117. Takanabe, K.; Aika, K.; Seshan, K.; Lefferts, L. Sustainable hydrogen from bio-oil—Steam reforming of acetic acid as a model oxygenate. J. Catal. 2004, 227, 101-108. [CrossRef]

118. Hossain, A.K.; Davies, P.A. Pyrolysis liquids and gases as alternative fuels in internal combustion engines-A review. Renew. Sustain. Energy Rev. 2013, 21, 165-189. [CrossRef]

119. Hossain, A.K.; Serrano, C.; Brammer, J.B.; Omran, A.; Ahmed, F.; Smith, D.I.; Davies, P.A. Combustion of fuel blends containing digestate pyrolysis oil in a multi-cylinder compression ignition engine. Fuel 2016, 171, 18-28. [CrossRef]

120. Vihar, R.; Seljak, T.; Oprešnik, S.R.; Katrašnik, T. Combustion characteristics of tire pyrolysis oil in turbo charged compression ignition engine. Fuel 2015, 150, 226-235. [CrossRef]

121. Martin, J.A.; Boateng, A.A. Combustion performance of pyrolysis oil/ethanol blends in a residential-scale oil-fired boiler. Fuel 2014, 133, 34-44. [CrossRef]

122. Shudo, T.; Nagano, T.; Kobayashi, M. Combustion characteristics of waste-pyrolysis gases in an internal combustion engine. Int. J. Automot. Technol. 2003, 4, 1-8.

123. Shah, A.; Srinivasan, R.; To, S.D.F.; Columbus, E.P. Performance and emissions of a spark-ignited engine driven generator on biomass based syngas. Bioresour. Technol. 2010, 101, 4656-4661. [CrossRef] [PubMed]

124. Hagos, F.Y.; Aziz, A.R.A.; Sulaiman, S.A. Trends of syngas as a fuel in internal combustion engines. Adv. Mech. Eng. 2014, 6, 401587. [CrossRef]

125. Kim, S.; Agblevor, F.A.; Lim, J. Fast pyrolysis of chicken litter and turkey litter in a fluidized bed reactor. J. Ind. Eng. Chem. 2009, 15, 247-252. [CrossRef]

126. Mante, O.D.; Agblevor, F.A. Parametric study on the pyrolysis of manure and wood shavings. Biomass Bioenergy 2011, 35, 4417-4425. [CrossRef]

127. Cao, J.; Xiao, X.; Zhang, S.; Zhao, X.; Sato, K.; Ogawa, Y.; Wei, X.Y.; Takarada, T. Preparation and characterization of bio-oils from internally circulating fluidized-bed pyrolyses of municipal, livestock, and wood waste. Bioresour. Technol. 2011, 102, 2009-2015. [CrossRef] [PubMed]

128. Cantrell, K.B.; Hunt, P.G.; Uchimiya, M.; Novak, J.M.; Ro, K.S. Impact of pyrolysis temperature and manure source on physicochemical characteristics of biochar. Bioresour. Technol. 2012, 107, 419-428. [CrossRef] [PubMed]

129. Yin, S.; Dolan, R.; Harris, M.; Tan, Z. Subcritical hydrothermal liquefaction of cattle manure to bio-oil: Effects of conversion parameters on bio-oil yield and characterization of bio-oil. Bioresour. Technol. 2010, 101, 3657-3664. [CrossRef] [PubMed]

130. Biller, P.; Ross, A.B. Potential yields and properties of oil from the hydrothermal liquefaction of microalgae with different biochemical content. Bioresour. Technol. 2011, 102, 215-225. [CrossRef] [PubMed] 
131. Peterson, A.A.; Vogel, F.; Lachance, R.P.; Fröling, M.; Antal, M.J.; Tester, J.W. Thermochemical biofuel production in hydrothermal media: A review of suband supercritical water technologies. Energy Environ. Sci. 2008, 1, 32-65. [CrossRef]

132. Duan, P.; Savage, P.E. Upgrading of crude algal bio-oil in supercritical water. Bioresour. Technol. 2011, 102, 1899-1906. [CrossRef] [PubMed]

133. Zhou, D.; Zhang, L.; Zhang, S.; Fu, H.; Chen, J. Hydrothermal liquefaction of macroalgae Enteromorpha prolifera to bio-oil. Energy Fuels 2010, 24, 4054-4061. [CrossRef]

134. Demirbas, F. Biorefineries for biofuel upgrading: A critical review. Appl. Energy 2009, 86, S151-S161. [CrossRef]

135. He, B.J.; Zhang, Y.; Funk, T.L.; Riskowski, G.L.; Yin, Y. Thermochemical conversion of swine manure: An alternative process for waste treatment and renewable energy production. Trans. ASAE 2000, 43, 1827-1833.

136. Xiu, S.; Shahbazi, A.; Wang, L.; Wallace, C.W. Supercritical ethanol liquefaction of swine manure for bio-oils production. Am. J. Eng. Appl. Sci. 2010, 3, 494-500. [CrossRef]

137. Bergman, P.C.; Kiel, J.H. Torrefaction for biomass upgrading. In Proceedings of the 14th European Biomass Conference \& Exhibition, Paris, France, 17-21 October 2005.

138. Qiu, Y.; Zheng, Z.; Zhou, Z.; Sheng, G.D. Effectiveness and mechanisms of dye adsorption on a straw-based biochar. Bioresour. Technol. 2009, 100, 5348-5351. [CrossRef] [PubMed]

139. Sohi, S.; Krull, E.; Lopez-Capel, E.; Bol, R. A review of biochar and its use and function in soil. Adv. Agron. 2010, 105, 47-82.

140. Ro, K.S.; Cantrell, K.B.; Hunt, P.G.; Ducey, T.F.; Vanotti, M.B.; Szogi, A.A. Thermochemical conversion of livestock wastes: Carbonization of swine solids. Bioresour. Technol. 2009, 100, 5466-5471. [CrossRef] [PubMed]

141. Chan, K.; Van Zwieten, L.; Meszaros, I.; Downie, A.; Joseph, S. Agronomic values of greenwaste biochar as a soil amendment. Soil Res. 2008, 45, 629-634. [CrossRef]

142. Keiluweit, M.; Nico, P.S.; Johnson, M.G.; Kleber, M. Dynamic molecular structure of plant biomass-derived black carbon (biochar). Environ. Sci. Technol. 2010, 44, 1247-1253. [CrossRef] [PubMed]

143. Bruun, E.W.; Hauggaard-Nielsen, H.; Ibrahim, N.; Egsgaard, H.; Ambus, P.; Jensen, P.A.; Dam-Johansen, K. Influence of fast pyrolysis temperature on biochar labile fraction and short-term carbon loss in a loamy soil. Biomass Bioenergy 2011, 35, 1182-1189. [CrossRef]

144. Unger, R.; Killorn, R. Effect of Three Different Qualities of Biochar on Selected Soil Properties. Commun. Soil Sci. Plant Anal. 2011, 42, 2274-2283. [CrossRef]

145. Shinogi, Y.; Yoshida, H.; Koizumi, T.; Yamaoka, M.; Saito, T. Basic characteristics of low-temperature carbon products from waste sludge. Adv. Environ. Res. 2003, 7, 661-665. [CrossRef]

146. Marchetti, R.; Castelli, F.; Orsi, A.; Sghedoni, L.; Bochicchio, D. Biochar from swine manure solids: Influence on carbon sequestration and Olsen phosphorus and mineral nitrogen dynamics in soil with and without digestate incorporation. Ital. J. Agron. 2012, 7, e26. [CrossRef]

147. Cantrell, K.B.; Martin, J.H. Stochastic state-space temperature regulation of biochar production. Part II: Application to manure processing via pyrolysis. J. Sci. Food Agric. 2012, 92, 490-495. [PubMed]

148. Tsai, W.T.; Liu, S.C.; Chen, H.R.; Chang, Y.M.; Tsai, Y.L. Textural and chemical properties of swine-manurederived biochar pertinent to its potential use as a soil amendment. Chemosphere 2012, 89, 198-203. [CrossRef] [PubMed]

149. Meyer, S.; Glaser, B.; Quicker, P. Technical, economical, and climate-related aspects of biochar production technologies: A literature review. Environ. Sci. Technol. 2011, 45, 9473-9483. [CrossRef] [PubMed]

(C) 2018 by the authors. Licensee MDPI, Basel, Switzerland. This article is an open access article distributed under the terms and conditions of the Creative Commons Attribution (CC BY) license (http://creativecommons.org/licenses/by/4.0/). 